A N N A L E S
U N I V ER S I T A T S M A R I A E C R I E-S K Ł O D O W S K A
L UBLIN - POLON I A

VOL. LXXV

SECTIO B

2020

DAGMARA KOCIUBA

https://orcid.org/0000-0001-9217-323X

Uniwersytet Marii Curie-Skłodowskiej w Lublinie

Wydział Nauk o Ziemi i Gospodarki Przestrzennej

al. Kraśnicka 2D, 20-718 Lublin

dagmara.kociuba@umcs.pl

\author{
EDYTA KOWALSKA \\ https://orcid.org/0000-0002-6014-5055 \\ Uniwersytet Marii Curie-Skłodowskiej w Lublinie \\ Wydział Nauk o Ziemi i Gospodarki Przestrzennej \\ al. Kraśnicka 2D, 20-718 Lublin \\ kowalskaa.edytaa@gmail.com
}

\title{
Rozwój przestrzenny byłych miast wojewódzkich w Polsce. Studium przypadku Krosna, Przemyśla i Tarnobrzega
}

Spatial Development of Former Voivodeship Capitals in Poland. Case Study of Krosno, Przemyśl and Tarnobrzeg

\begin{abstract}
The decentralisation of the country's territorial system had an immense impact on the development of cities at the turn of the $20^{\text {th }}$ and $21^{\text {st }}$ centuries. This particularly concerns former capitals of voivodeships "degraded" to the function of poviat cities, facing a number of socio-economic challenges, reflected in among others their spatial development. The objective of the paper is the identification of their conditions, common features, and differences, as well as determination of directions of changes in the process of spatial development of former voivodeship capitals in Poland. The paper discusses the following issues: 1) effect of expansion of administrative boundaries on changes in the functional-spatial structure; 2) stimulants and destimulants of spatial development; 3) shaping the spatial structure in reference to the historical development of cities and provisions of strategic-planning documents; 4) functional urban areas; 5) directions of spatial development of the analysed cities in the future. They correspond with the detailed objectives. The contribution of this paper is twofold. In the implementation aspect, it presents the effect of the political transformation, administrative-territorial reforms, and conducted spatial policy on the development of cities constituting voivodeship capitals until 1998, i.e. Krosno, Przemyśl, and Tarnobrzeg, currently located in the Carpathian Voivodeship. In the cognitive aspect, it presents models of spatial development of these cities.
\end{abstract}

Keywords: spatial development of former voivodeship capitals; models of spatial development; former voivodeship capitals; Krosno; Tarnobrzeg; Przemyśl; Poland

Abstrakt: Decentralizacja ustroju terytorialnego państwa wywarła ogromny wpływ na rozwój miast na przełomie XX i XXI w. Dotyczy to zwłaszcza byłych stolic województw „,zdegradowanych” 
do funkcji miast na prawie powiatu, przed którymi stanęło wiele wyzwań natury społeczno-gospodarczej, co znalazło odzwierciedlenie m.in. w ich rozwoju przestrzennym. Celem opracowania jest zidentyfikowanie uwarunkowań, cech wspólnych i różnic, a także wskazanie kierunków zmian $\mathrm{w}$ procesie rozwoju przestrzennego byłych miast wojewódzkich w Polsce. W pracy odniesiono się do takich zagadnień, jak: 1) wpływ rozszerzenia granic administracyjnych na zmiany struktury funkcjonalno-przestrzennej; 2) stymulanty i destymulanty rozwoju przestrzennego; 3) kształtowanie struktury przestrzennej w nawiązaniu do historycznego rozwoju miast oraz zapisów dokumentów strategiczno-planistycznych; 4) miejskie obszary funkcjonalne; 5) kierunki rozwoju przestrzennego analizowanych miast w przyszłości. Odpowiadają one układowi celów szczegółowych. Efekty niniejszej pracy są dwojakie. W aspekcie implementacyjnym ukazano wpływ transformacji ustrojowej, reform administracyjno-terytorialnych oraz prowadzonej polityki przestrzennej na rozwój miast będących do 1998 r. stolicami województw, tj. Krosna, Przemyśla i Tarnobrzega, położonych obecnie w województwie podkarpackim. W aspekcie poznawczym opracowano modele rozwoju przestrzennego tych miast.

Słowa kluczowe: rozwój przestrzenny byłych miast wojewódzkich; modele rozwoju przestrzennego; byłe miasta wojewódzkie; Krosno; Tarnobrzeg; Przemyśl; Polska

\section{WSTĘP}

Rozwój przestrzenny wynika z prowadzonej polityki przestrzennej, która determinuje cele, kierunki i zasady kształtowania i zagospodarowania przestrzeni oraz określa różnego rodzaju instrumenty rozwoju (Szlachta 1996). Wiąże się on ściśle z planowaniem przestrzennym, które wspomaga politykę przestrzenną i usprawnia mechanizm podejmowania decyzji przestrzennych wraz z instrumentami jej realizacji (Borsa 2008). Rozwój przestrzenny warunkowany jest przez różnego rodzaju determinanty rozwoju lokalnego o charterze endo- i egzogenicznym, wśród których wyróżnia się zarówno stymulanty (czynniki), jak i destymulanty (ograniczenia, progi, bariery) (Rogowska 2010). W przypadku rozwoju miast najistotniejszą rolę odgrywają czynniki polityczno-ustrojowe, społeczne, demograficzne, ekonomiczne, przestrzenne, techniczne i naturalne (ekologiczne) (Domański 1990; Bagdziński 1994; Parysek 1997, 2018; Kosiedowski 2008). Do powszechnie występujących czynników o charakterze ogólnym można zaliczyć m.in. potrzeby społeczności lokalnych, zasoby i walory środowiska przyrodniczego, zainwestowanie infrastrukturalne, zasoby pracy, istniejący potencjał gospodarczy, rynek lokalny i rynki zewnętrzne, teren i korzyści miejsca (Parysek 1997). Z kolei bariery stanowią ograniczenie dla harmonijnego rozwoju miast (Maik, Parysek, Wojtasiewicz 1978). Istnieje wiele ich rodzajów (Sekuła 2005); mogą mieć różne przyczyny (np. fizyczne, funkcjonalne, technologiczne, strukturalne; zob. Malisz, Żurkowski 1971), różny też może być ich charakter (np. progi przestrzenne, terenowe oraz ilościowe; zob. Regulski 1982). Do klasycznych ograniczeń zalicza się m.in. przestarzałą infrastrukturę techniczną, 
społeczną i budownictwa mieszkaniowego, deficyty wolnych obszarów (w tym uzbrojonych), dewastację środowiska przyrodniczego (Parysek 1997), a także bariery związane z planowaniem przestrzennym miast (Kociuba 2015b).

$\mathrm{Na}$ rolę i pozycję miast $\mathrm{w}$ systemie osadniczym kraju oddziałują skutki reform terytorialnych oraz przemiany ustrojowe (Krzysztofik 2014; Tomaszewski 2019). W odniesieniu do Polski w pierwszym przypadku decydująca była reforma z 1990 r. (Ustawa z dnia 8 marca 1990 r. o samorządzie gminnym, Dz.U. 1990, nr 16, poz. 95 ze zm.), która zniosła termin „miasto”, wprowadzając na to miejsce pojęcie gminy miejskiej, a także reforma z 1998 r. (Ustawa z dnia 24 lipca 1998 r. o wprowadzeniu zasadniczego trójstopniowego podziału terytorialnego państwa, Dz.U. 1998, nr 96, poz. 603), która zamiast 49 województw wprowadziła 16, a większość miast wojewódzkich „zdegradowała” do roli miast na prawie powiatu (Kulesza 2000). W tej sytuacji byłe miasta wojewódzkie utraciły większość dawniej pełnionych funkcji (Tomaszewski 2019). Dodatkowo nałożyły się na to skutki transformacji ustrojowej, w postaci m.in. przemian własnościowych, demonopolizacji gospodarki, wzrostu poziomu bezrobocia oraz zubożenia społeczeństwa, pogłębiających się różnic międzyregionalnych czy braku prowadzenia konsekwentnej polityki strategicznej państwa (Mikołajewicz 2003).

Transformacja ustrojowa i reformy terytorialne oparte były na zmianach ustawowych, które wywarły znaczący wpływ na rozwój przestrzenny miast. Do istotnych zmian należy zaliczyć wejście w życie ustawy z dnia 7 lipca $1994 \mathrm{r}$. o zagospodarowaniu przestrzennym (Dz.U. 1994, nr 89, poz. 415 ze zm.), którą zastąpiła ustawa $\mathrm{z}$ dnia 27 marca $2003 \mathrm{r}$. o planowaniu i zagospodarowaniu przestrzennym (Dz.U. 2003, nr 80, poz. 717 ze zm.). Wprowadziły one nowe zasady prowadzenia polityki przestrzennej oraz przypisane jej nowe narzędzia. Zalicza się do nich przede wszystkim pojawienie się jako obligatoryjnego studium uwarunkowań i kierunków zagospodarowania przestrzennego (SUiKZP), które nie ma mocy prawa miejscowego, a jest jedynie instrumentem kształtowania polityki przestrzennej, a także wprowadzenie zasady dobrowolności opracowania miejscowych planów zagospodarowania przestrzennego (MPZP), co doprowadziło do ich znacznego rozproszenia, prowadzącego w efekcie do braku spójności przestrzennej. Tę niekorzystną sytuację pogorszyło wprowadzenie decyzji o warunkach zabudowy i zagospodarowania terenu, która jest obecnie jednym z najczęściej wykorzystywanych narzędzi realizacji polityki przestrzennej w procesie planowania przestrzennego (Parysek 2010, 2018). Doprowadziło to do nasilenia chaosu urbanistycznego i zwiększyło tempo „rozlewania się” miast (Kudłacz 2016).

W kontekście rozwoju przestrzennego najbardziej niekorzystnym zjawiskiem jest niekontrolowana suburbanizacja, gdyż prowadzi do odpływu ludności z miast w strefy podmiejskie (Małek 2011). Wiąże się to z chaotycznym rozrostem 
tych stref, często z brakiem poszanowania zasad ładu przestrzennego oraz ze wzrostem kosztów ponoszonych zarówno przez gminy podmiejskie, jak i same miasta (Kowalewski, Mordasewicz, Osiatyński, Regulski, Stępień, Śleszyński 2014; Kudłacz 2016), które przyjmują na siebie szereg obowiązków w zakresie obsługi mieszkańców, nie czerpiąc z tego tytułu adekwatnych zysków (Harasimowicz 2018). Stanowi to zagrożenie nie tylko dla prowadzenia efektywnej polityki rozwoju, ale też niesie za sobą wiele negatywnych skutków społecznych, gospodarczych i środowiskowych (Lisowski, Grochowski 2008) oraz ograniczeń w zakresie planowania przestrzennego (Jędraszko 2005; Kociuba 2015a).

Miały temu zapobiec działania podjęte w ramach wprowadzania nowego paradygmatu polityki ukierunkowanej terytorialnie, bazujące na wykorzystaniu endogenicznych potencjałów terytoriów określonych funkcjonalnie, integracji działań publicznych w wymiarze przestrzennym oraz wprowadzeniu wielopoziomowego systemu zarządzania. Znalazło to odzwierciedlenie m.in. w wyodrębnieniu w Koncepcji Przestrzennego Zagospodarowania Kraju (KPZK) 2030 (2011) nowych jednostek terytorialnych, tj. miejskich obszarów funkcjonalnych (MOF) obejmujących zwarty obszar miejski oraz powiązaną z nim funkcjonalnie strefę zurbanizowaną. Ich zrównoważony rozwój w okresie programowania 2014-2020 uzyskał dodatkowe wsparcie w ramach nowego narzędzia polityki spójności, tj. Zintegrowanych Inwestycji Terytorialnych (ZIT). Jednym z wymogów uzyskania finansowania było zawiązanie współpracy między jednostkami samorządu terytorialnego (JST) (Kaczmarek, Kociuba 2017), delimitacja obszaru wsparcia (Kociuba 2017) oraz opracowanie dokumentu strategicznego (strategii ZIT) dla całego terytorium obszaru funkcjonalnego (Kociuba 2018). Pomimo tego, że ZIT są dedykowane przede wszystkim MOF ośrodków wojewódzkich, część miast regionalnych i subregionalnych również zdecydowała się na ich realizację (Nowakowska 2017; Noworól 2018; Szafranek 2019).

Kolejnym działaniem zapobiegającym niekontrolowanemu rozrostowi miast (urban sprawl) oraz warunkującym ich prawidłowy rozwój przestrzenny jest poszerzanie granic miasta i przyłączanie zagospodarowanych na sposób miejski stref podmiejskich oraz terenów stanowiących zaplecze rozwojowe (Kociuba 2019). Należy przy tym zauważyć, że proces ten w ostatnich latach ulega znaczącym modyfikacjom, pojawiają się nowe trendy, a decyzje w tym zakresie nie zawsze odzwierciedlają potrzeby jednostek i często stają się elementem gry politycznej (Kociuba [w druku]).

Wszystko to sprawia, że przed byłymi miastami wojewódzkimi stanęło wiele wyzwań, a działania prowadzone przez władze lokalne znalazły odzwierciedlenie m.in. w rozwoju przestrzennym tych ośrodków. Celem niniejszej pracy jest ukazanie uwarunkowań i efektów rozwoju przestrzennego byłych miast 
wojewódzkich w Polsce. Wkład opracowania jest dwojaki. W aspekcie implementacyjnym ukazano wpływ czynników przyrodniczych (wody, rzeźba terenu, bogactwa naturalne), historycznych (m.in. położenie na szlakach handlowych, rozwój przemysłu) i współczesnych (m.in. transformacja ustrojowa, reformy administracyjno-terytorialne, zmiany granic oraz skutki prowadzonej polityki przestrzennej) na kierunki rozwoju przestrzennego byłych stolic województw, a także wykazano podobieństwa i różnice w tym zakresie. W aspekcie poznawczym przedstawiono modele struktury przestrzennej tych miast. Do analiz wybrano dawne stolice województw, tj. Krosno, Przemyśl i Tarnobrzeg, położone w województwie podkarpackim. W toku analiz uzyskano odpowiedź na pięć pytań badawczych, odpowiadających układowi celów szczegółowych:

1. Czy rozszerzenia granic administracyjnych miały wpływ na zmiany struktury funkcjonalno-przestrzennej?

2. Jakie są stymulanty i destymulanty rozwoju przestrzennego analizowanych miast?

3. Czy dokumenty planistyczne uwzględniają historyczny i współczesny rozwój miast?

4. Czy MOF-y stanowią kontynuację rozwoju przestrzennego ośrodków?

5. Jak analizowane jednostki powinny rozwijać się w przyszłości?

\section{OBSZAR BADAŃ}

Obszar badań stanowią trzy byłe miasta wojewódzkie (obecnie są to miasta na prawach powiatu) położone w województwie podkarpackim: Krosno, Przemyśl i Tarnobrzeg (ryc. 1). Są to miasta średniej wielkości (40-60 tys. mieszkańców). Pod względem liczby ludności i gęstości zaludnienia największy jest Przemyśl, a biorąc pod uwagę powierzchnię - Tarnobrzeg (tab. 1).

Tab. 1. Liczba ludności, powierzchnia i gęstość zaludnienia Krosna, Przemyśla i Tarnobrzega w 2018 r. (opracowanie własne na podstawie www.bdl.stat.gov.pl)

Table 1. Population, area and population density of Krosno, Przemyśl and Tarnobrzeg in 2018 (own elaboration based on www.bdl.stat.gov.pl)

\begin{tabular}{|l|c|c|c|}
\hline \multicolumn{1}{|c|}{ Kryterium } & Krosno & Przemyśl & Tarnobrzeg \\
\hline Liczba ludności (l. os.) & 46532 & 61251 & 47047 \\
\hline Powierzchnia $\left(\mathrm{km}^{2}\right)$ & 43,5 & 46,2 & 85,4 \\
\hline Gęstość zaludnienia (os. $\left./ \mathrm{km}^{2}\right)$ & 1069 & 1326 & 551 \\
\hline
\end{tabular}

Według podziału fizycznogeograficznego Polski (Solon i in. 2018) miasta położone są na terenie megaregionu Karpaty, Podkarpacie i Nizina Panońska (5), 


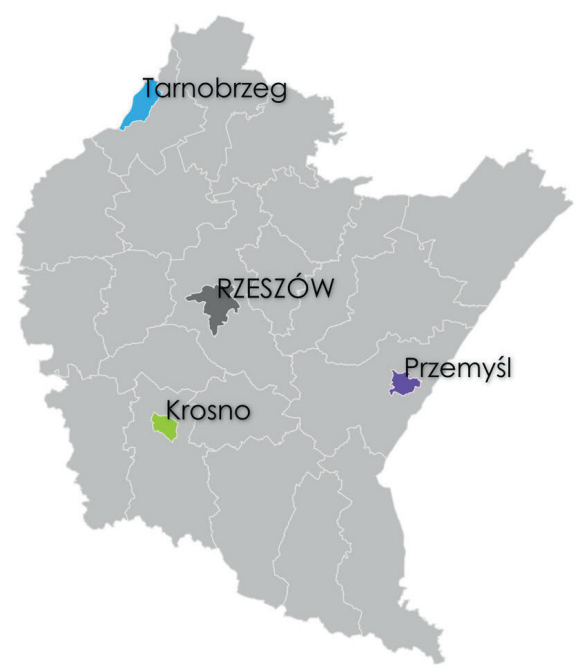

Ryc. 1. Lokalizacja Krosna, Przemyśla i Tarnobrzega w województwie podkarpackim (opracowanie własne na podstawie GUGiK 2019)

Fig. 1. Location of Krosno, Przemyśl and Tarnobrzeg in the Carpathian Voivodeship (own elaboration based on GUGiK 2019)

w prowincji Karpaty Zachodnie z Podkarpaciem Zachodnim i Północnym (512). Najbardziej zróżnicowaną rzeźbę terenu ma Przemyśl, leżący w obrębie pięciu mezoregionów: Płaskowyż Sańsko-Dniestrzański (521.1), Pradolina Podkarpacka (512.51), Pogórze Rzeszowskie (512.52), Pogórze Dynowskie (513.64) oraz Pogórze Przemyskie (513.65). Krosno, położone w Kotlinie Jasielsko-Krośnieńskiej (513.67), charakteryzuje lekko pofałdowana rzeźba terenu. Z kolei Tarnobrzeg leży w północnej części Kotliny Sandomierskiej na zalewowej części Niziny Nadwiślańskiej (512.41).

Wszystkie charakteryzowane miasta położone są w dorzeczu Wisły, bezpośrednio w jej sąsiedztwie (Tarnobrzeg) lub nad jej prawobrzeżnymi dopływami (Przemyśl nad Sanem, a Krosno nad Wisłokiem). W Tarnobrzegu znajduje się drugi pod względem wielkości sztuczny zbiornik wodny na Podkarpaciu, tj. Jezioro Tarnobrzeskie. Ze względu na swe położenie omawiane miasta są narażone na powodzie. Największa strefa zagrożenia powodziowego znajduje się w Tarnobrzegu (ok. $55 \%$ powierzchni miasta - poza zasięgiem prawdopodobnych zalewów znajdują się tereny położone na terasie wysokiej Wisły, tzn. centrum miasta oraz osiedle Miechocin). W Przemyślu strefa zagrożenia powodziowego obejmuje tereny położone wzdłuż rzek San i Wiar (ok. 37\% powierzchni miasta). Szczególnie narażone są cztery osiedla: Wilcza, Przekopana, Sielec i Lwowskie, leżące we wschodniej części miasta. W Krośnie tereny zagrożone powodzią występują w dolinie rzeki Wisłok i potoku Lubatówka (ok. 9\% powierzchni miasta) (ryc. 2). 

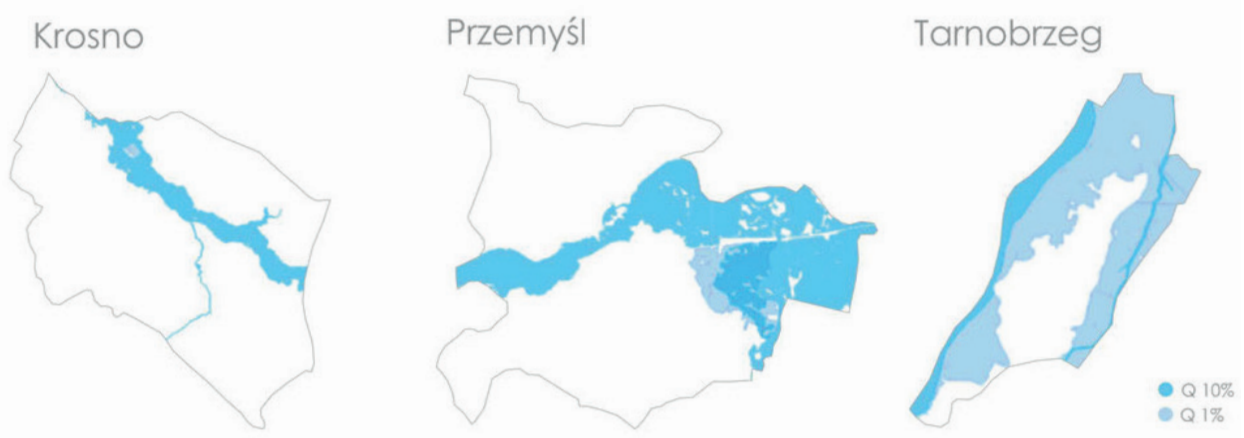

Ryc. 2. Zagrożenie powodziowe w Krośnie, Przemyślu i Tarnobrzegu (opracowanie własne na podstawie danych ISOK)

Fig. 2. Flood risk in Krosno, Przemyśl and Tarnobrzeg (own elaboration based on ISOK data)

Analizowane ośrodki są zasobne w surowce mineralne. Baza surowcowa Krosna obejmuje surowce bitumiczne, tj. gaz ziemny i ropę naftową. W Przemyślu występują złoża gazu oraz surowce ceramiczne, natomiast w Tarnobrzegu - pokłady siarki rodzimej. Niewielkie powierzchnie analizowanych miast (do 10\%) są objęte różnymi formami ochrony przyrody, najczęściej zlokalizowanymi w dolinach rzek, a w Przemyślu zajmującymi również południowo-zachodnie krańce miasta ${ }^{1}$. W przypadku Przemyśla należy podkreślić, że ze względu na właściwości podłoża (lessy) i urozmaiconą rzeźbę istnieje ryzyko wystąpienia erozji gleb i procesów masowych (szczególnie w obrębie wierzchowiny lessowej położonej w północnej, północno-zachodniej i południowo-zachodniej części miasta).

Miasta różnią się uwarunkowaniami historycznymi. Przemyśl i Krosno to stare ośrodki miejskie, lokowane w średniowieczu, położone na szlakach komunikacyjnych wiodących na Węgry i Ruś. Tarnobrzeg to miasto szlacheckie, lokowane w końcu XVI w. (Janas, Wójcik, Pietras 1999). Osady były wielokrotnie niszczone w wyniku wojen, m.in. w potopie szwedzkim (1655-1660). W $1772 \mathrm{r}$. w wyniku pierwszego rozbioru Polski miasta te znalazły się pod panowaniem Habsburgów. W XIX w. w Krośnie odkryto złoża ropy naftowej, a w 1856 r. rozpoczęto ich eksploatację (Michalak 1996). Przemyśl w wyniku pogarszających się stosunków z Rosją przebudowano w fortecę (1850), natomiast w Tarnobrzegu utworzono zakłady przemysłowe, m.in. browar i parową wytwórnię

1 W Krośnie są to obszar Natura 2000 Wisłok Środkowy z Dopływami, Czarnorzecki Obszar Chronionego Krajobrazu oraz użytek ekologiczny „Dolina potoku Badoń”; w Przemyślu - Park Krajobrazowy Pogórza Przemyskiego, rezerwaty przyrody „Jamy” i „Winna Góra”, Przemysko-Dynowski Obszar Chronionego Krajobrazu oraz obszary Natura 2000: Ostoja Przemyska, Rzeka San i Pogórze Przemyskie; w Tarnobrzegu - dwa obszary Natura 2000: Tarnobrzeska Dolina Wisły oraz Puszcza Sandomierska. 
stolarską (Motak 2004). Podczas I i II wojny światowej miasta były sukcesywnie niszczone. Po zakończeniu działań wojennych przystąpiono do odbudowy ośrodków. W Krośnie ponownie uruchomiono kopalnie ropy naftowej oraz hutę szkła, w Przemyślu odbudowano szereg starych fabryk i rozpoczęto wydobycie gazu ziemnego, a w Tarnobrzegu odkryto pokłady siarki (1953), co przyczyniło się do utworzenia czterech kopalń wydobywających ten surowiec. Prace górnicze na terenie Tarnobrzega trwały w latach 1969-1992 (Szmuc, Madej 2011).

Krosno, Przemyśl i Tarnobrzeg najlepiej prosperowały w latach 1975-1998, kiedy pełniły rolę stolic województw (Tomaszewski 2019). W związku z dobrą koniunkturą przemysłu we wszystkich ośrodkach następował wzrost liczby ludności. Transformacja ustrojowa otworzyła przed nimi nowe możliwości, które jednak nie zostały w pełni wykorzystane. Znaczące zahamowanie rozwoju społeczno-gospodarczego ośrodków nastąpiło tuż po przeprowadzonej w 1998 r. reformie administracyjnej (Tokarski, Wilk-Jakubowski, Misiak 2012). W ostatnich latach sytuacja gospodarcza uległa niewielkiej poprawie. Dotyczy to m.in. rynku pracy, gdzie odnotowano spadek stopy bezrobocia rejestrowanego oraz wzrost kwoty średniego wynagrodzenia. Liczba podmiotów gospodarczych znajdujących się w rejestrze REGON na 1000 mieszkańców od 2005 r. kształtuje się na podobnym poziomie (ok. 100). Pod względem poziomu przedsiębiorczości wyróżnia się Krosno, gdzie wskaźnik ten jest wyższy (120) przy jednocześnie niskiej stopie bezrobocia rejestrowanego (3\%). Sytuacja finansowa miast również uległa poprawie. Z upływem lat obserwuje się wzrost przychodów i wydatków samorządów. W tym zakresie również wyróżnia się Krosno (7002 zł i 7703 zł na mieszkańca). W 2017 r. najbardziej zadłużonym miastem był Tarnobrzeg (56\% dochodów budżetowych), a następnie Przemyśl (53\%) i Krosno (42\%). Zadłużenie Tarnobrzega ma tendencję spadkową, natomiast Krosna i Przemyśla - wzrostową. Dodatkowo miasta aktywnie pozyskują środki unijne na prowadzone inwestycje. W perspektywie finansowej 2007-2013 i 2014-2020 podpisano łącznie 783 umowy na kwotę 1,8 mld zł. Ponownie jest tu widoczna dominacja Krosna (1,4 mld zł). W przypadku Przemyśla i Tarnobrzega kwoty są porównywalne (ok. $720 \mathrm{mln}$ zf). Wszystkie analizowane miasta korzystają ze wsparcia w ramach ZIT, przy czym najwięcej projektów (40 na kwotę 215,2 mln zł) jest obecnie realizowanych w MOF Przemyśla. Mniejsze finansowanie otrzymały MOF Krosna (147,9 mln zł na realizację 11 projektów) i MOF Tarnobrzega (130,8 $\mathrm{mln}$ zł na realizację 6 projektów).

Niestety, nie ulega poprawie sytuacja demograficzna omawianych byłych stolic województw. Obecnie odnotowuje się tu stały ubytek liczby mieszkańców. Do 2050 r. szacuje się, że populacja Krosna zmniejszy się o ok. 27\%, Przemyśla - o 25\%, a Tarnobrzega - o 28\% (GUS 2014). Saldo migracji oraz przyrost 
naturalny również odznaczają się coraz niższymi wartościami. Obserwuje się stały odpływ ludności i starzenie się społeczeństwa.

\section{MATERIAŁY I METODY}

Materiały źródłowe stanowiły dane kartograficzne i statystyczne, akty prawne oraz dokumenty planistyczne i strategiczne. Wśród wykorzystanych materiałów kartograficznych znalazły się m.in. dane z państwowego rejestru granic i powierzchni jednostek podziałów terytorialnych kraju Głównego Urzędu Geodezji i Kartografii (GUGiK), ortofotomapa pozyskana z geoportalu krajowego, informacje geoprzestrzenne udostępnione przez Generalną Dyrekcję Ochrony Środowiska (GDOŚ), dane z Informatycznego Systemu Osłony Kraju (ISOK) przed nadzwyczajnymi zagrożeniami, OpenStreetMap (OSM), materiały z geoportali miast Krosna, Przemyśla i Tarnobrzega, arkusze mapy hydrologicznej i geośrodowiskowej Polski. Dane statystyczne dla charakteryzowanych miast z lat 1995-2019 zostały pozyskane z Banku Danych Lokalnych (BDL). Dotyczyły one m.in. demografii, rynku pracy, finansów publicznych, stanu środowiska, podziału terytorialnego.

$\mathrm{W}$ pracy przeanalizowano również uwarunkowania prawne dotyczące zagospodarowania przestrzennego i rozwoju miast oraz zmian terytorialno-administracyjnych. Odniesiono się m.in. do ustawy o planowaniu i zagospodarowaniu przestrzennym (Dz.U. 2003, nr 80, poz. 717 ze zm.), ustawy o wprowadzeniu zasadniczego trójstopniowego podziału terytorialnego państwa (Dz.U. 1998, nr 96, poz. 603), Koncepcji Przestrzennego Zagospodarowania Kraju 2030 (M.P. 2012, poz. 252), Planu Zagospodarowania Przestrzennego Województwa Podkarpackiego z Perspektywą do 2030 r. (L1X/930/18), a także zapisów trzynastu rozporządzeń Rady Ministrów odnośnie do zmian granic administracyjnych Krosna, Przemyśla i Tarnobrzega. Wykorzystano też informacje pochodzące z dokumentów strategiczno-planistycznych na poziomie lokalnym (strategie rozwoju, SUiKZP oraz łącznie 152 obowiązujące MPZP) oraz miejskich obszarów funkcjonalnych (strategie ZIT).

Na podstawie studiów literaturowych, danych kartograficznych i statystycznych przeanalizowano uwarunkowania rozwojowe miast w zakresie zmian granic administracyjnych, struktury funkcjonalno-przestrzennej i kierunków zmian zagospodarowania. Dało to podstawę do opracowania modeli rozwoju przestrzennego analizowanych miast. Za punkt wyjścia przyjęto modele: koncentryczny (Burgess 1925), sektorowy (klinowy) (Hoyt 1939) oraz policentryczny (wieloośrodkowy) (Harris, Ullman 1945). Przyjęto definicję A. Werwickiego (1973), według której układ przestrzenny to rozmieszczenie różnych typów działalności ludzkiej, a także związanych z nimi urządzeń trwałych, wśród których jako najważniejsze dla określenia wewnętrznego zróżnicowania terytorium miejskiego 
uznaje się powszechnie zabudowę mieszkaniową, przemysłową oraz urządzenia związane z usługami i komunikacją. Wyróżniono następujące układy przestrzenne: 1) koncentryczny, ukazujący przyrost terenów zajętych pod działalność ludzką i związanych z nią urządzeń trwałych wokół centrum miasta; 2) policentryczny, w którym funkcjonuje kilka odrębnych ośrodków osadniczych lub odrębnych skupisk terenów zróżnicowanych funkcjonalnie; 3) pasmowy, w którym istnieją silnie zróżnicowane funkcjonalnie tereny układające się w postaci pasm wzdłuż ciągów komunikacyjnych; 4) pasmowo-koncentryczny, w którym pasma zbiegają się w ośrodku węzłowym, a ponadto występuje zjawisko narastania terenów o różnych funkcjach wokół centrum miasta lub dzielnicy centralnej; 5) pasmowo-koncentryczno-policentryczny, stanowiący rozwinięcie układu pasmowo-koncentrycznego o elementy policentryczne.

\section{WYNIKI BADAŃ}

\section{Rozwój przestrzenny badanych miast w XX i na początku XXI w.}

Od początku XX w. granice administracyjne analizowanych miast ulegały wielokrotnie zmianom, co miało wpływ m.in. na przekształcanie ich struktury przestrzennej. Najwięcej zmian granic miało miejsce w latach 50. i 70. XX w. Krosno czterokrotnie powiększało swój obszar. Do miasta w latach 1924-1972 łącznie przyłączono 3267 ha. Po przejęciu w 2018 r. terenów dawnego lotniska sportowego Iwonicz (122 ha), położonego przy południowo-wschodnich granicach miasta w gminach Krościenko Wyżne i Miejsce Piastowe, władze Krosna prowadziły działania mające na celu przyłączenie tego terenu. W $2020 \mathrm{r}$. zakończyły się one sukcesem - od 1 stycznia 2021 r. teren lotniska znajdzie się w granicach administracyjnych Krosna (Rozporządzenie Rady Ministrów z dnia 31 lipca 2020 r., Dz.U. 2020, poz. 1332). Obecnie w mieście funkcjonuje 12 jednostek pomocniczych, w tym 6 dzielnic (Białobrzegi, Krościenko Niżne, Polanka, Śródmieście, Suchodół, Zawodzie) i 6 osiedli (Markiewicza, Południe, Grota-Roweckiego, Traugutta, Turaszówka, Tysiąclecia) (ryc. 3).

Granice Przemyśla również ulegały czterokrotnemu poszerzeniu. Łącznie do miasta w latach 1956-2009 włączono obszar o powierzchni 2850 ha. W 2019 r. zarządzeniem nr 72/2019 Prezydenta Miasta Przemyśla powołano Zespół ds. zmiany granic miasta, kontynuując tym samym dalsze prace nad procesem ekspansji terytorialnej jednostki. W Przemyślu znajdują się 22 osiedla, które mają status jednostek pomocniczych (ryc. 4).

Tarnobrzeg pięciokrotnie zmieniał swoje granice. W latach 1934-1991 do miasta przyłączono 10 miejscowości o łącznej powierzchni 6843 ha. Tarnobrzeg w 2019 r. posiadał 16 jednostek pomocniczych (osiedli) (ryc. 5). 

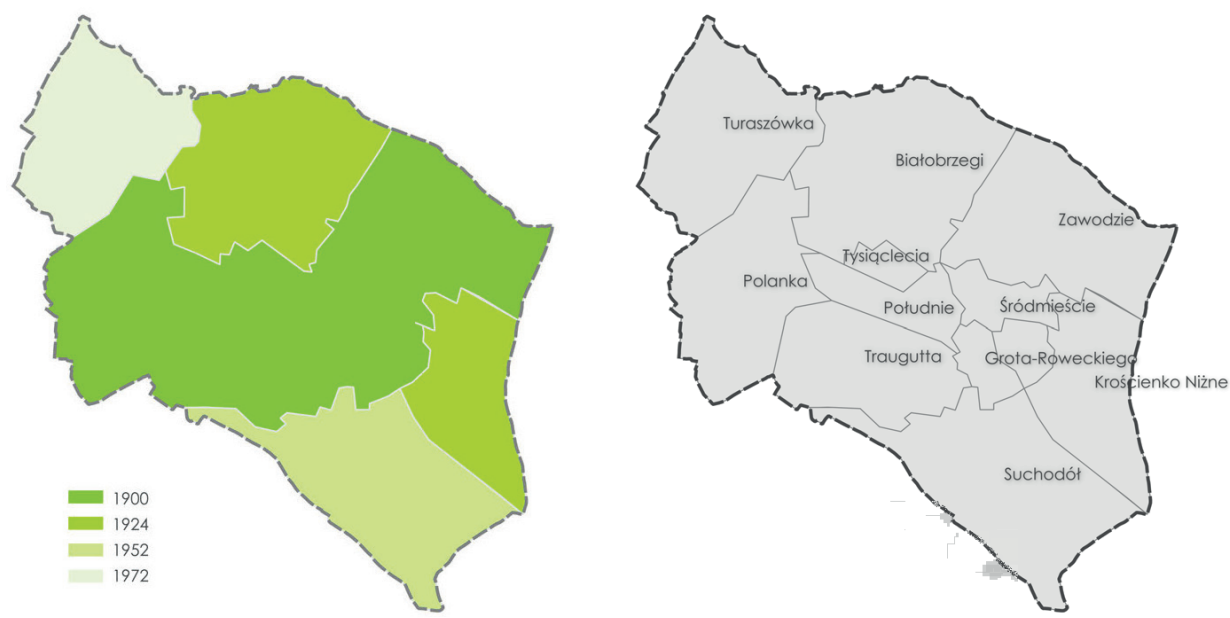

Ryc. 3. Zmiany granic administracyjnych Krosna od początku XX w. oraz podział miasta na jednostki pomocnicze (opracowanie własne na podstawie GUGiK i OSM)

Fig. 3. Changes in the administrative boundaries of Krosno since the beginning of the $20^{\text {th }}$ century and the division of the city into auxiliary units (own elaboration based on GUGiK and OSM)
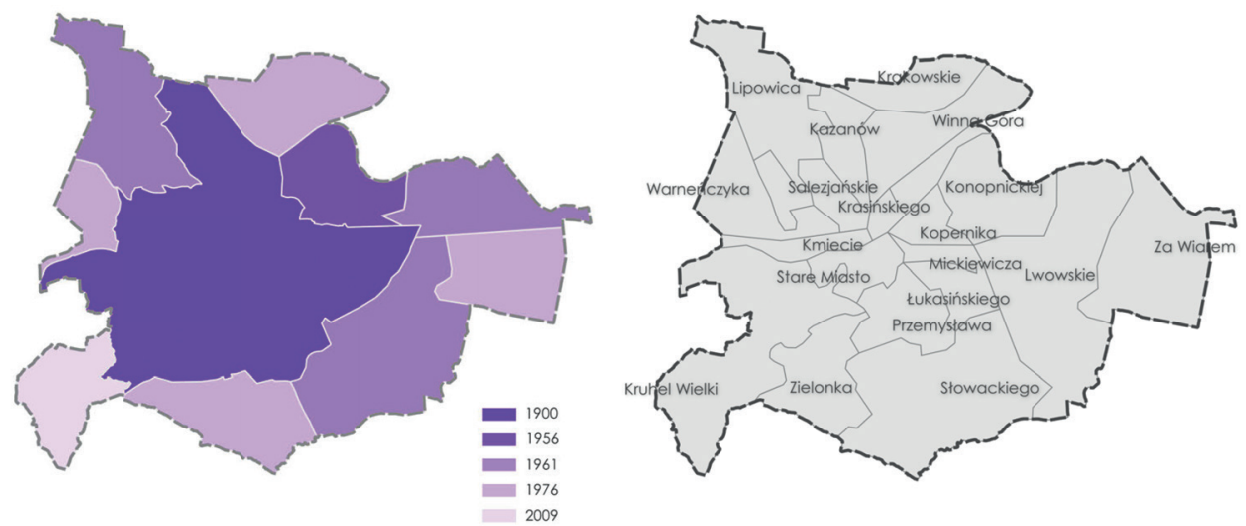

Ryc. 4. Zmiany granic administracyjnych Przemyśla od początku XX w. oraz podział miasta na jednostki pomocnicze (opracowanie własne na podstawie GUGiK i OSM)

Fig. 4. Changes in the administrative boundaries of Przemyśl since the beginning of the $20^{\text {th }}$ century and the division of the city into auxiliary units (own elaboration based on GUGiK and OSM)

Podsumowując zmiany granic analizowanych miast, należy podkreślić, że tylko Tarnobrzeg posiada rezerwę terenów pod rozbudowę $\left(85,4 \mathrm{~km}^{2}\right.$ przy 47 tys. ludności), aczkolwiek ponad jej połowa znajduje się na obszarach zalewowych. Zajmujące o połowę mniejsze powierzchnie Przemyśl i Krosno starają się o poszerzenie swoich granic administracyjnych (Krosno z sukcesem). Wynika to poniekąd z warunków naturalnych oraz istniejącej struktury funkcjonalno-przestrzennej, 

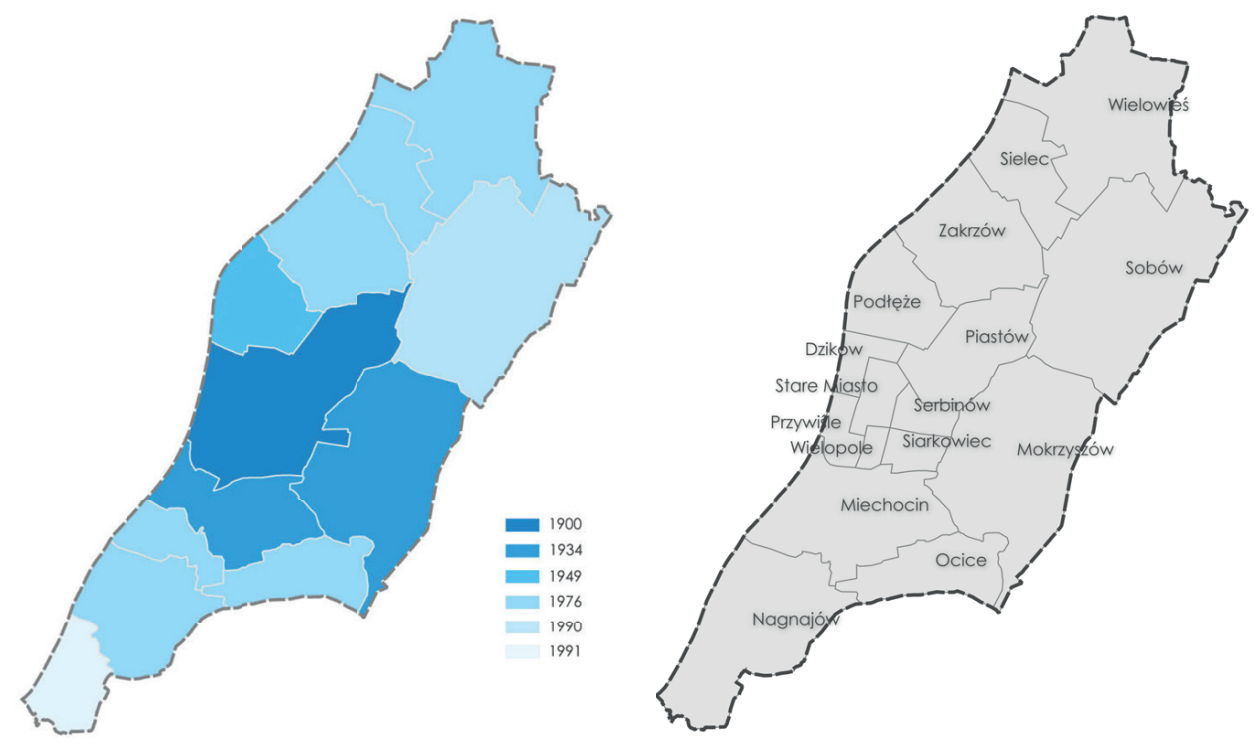

Ryc. 5. Zmiany granic administracyjnych Tarnobrzega od początku XX w. oraz podział miasta na jednostki pomocnicze (opracowanie własne na podstawie GUGiK i OSM)

Fig. 5. Changes in the administrative boundaries of Tarnobrzeg since the beginning of the $20^{\text {th }}$ century and the division of the city into auxiliary units (own elaboration based on GUGiK and OSM)

stosunków własnościowych i udziału terenów zainwestowanych, co jest przedmiotem analizy w następnej części pracy.

\section{Struktura funkcjonalno-przestrzenna analizowanych miast}

Struktura użytkowania gruntów w analizowanych miastach jest zróżnicowana. W zajmującym $43,5 \mathrm{~km}^{2}$ powierzchni Krośnie najwięcej obszarów stanowią tereny zabudowy mieszkaniowej (47\% powierzchni miasta) i obszary rolnicze (23\%). W zajmującym 46,2 $\mathrm{km}^{2}$ powierzchni Przemyślu największy obszar również jest zajęty pod tereny zabudowy mieszkaniowej (35\% powierzchni miasta), a w drugiej kolejności pod lasy, tereny zielone i nieużytki (łącznie 29\%). Największy obszar mającego $85,4 \mathrm{~km}^{2}$ powierzchni Tarnobrzega - w przeciwieństwie do Krosna i Przemyśla - stanowią lasy, tereny zielone i nieużytki (31\% powierzchni miasta), a także obszary rolnicze (28\%) (tab. 2).

Analizowane miasta mają odmienną strukturę funkcjonalno-przestrzenną. W Krośnie uwarunkowania historyczne zdecydowały o tym, że główne skupisko zabudowy mieszkaniowej znajduje się w centrum miasta i rozciąga się wzdłuż linii kolejowej oraz rzeki Wisłok. Tereny przemysłowe usytuowane są na zachód od centrum Krosna. Dawniej istniały tu szyby wydobywcze i destylarnia ropy naftowej. Do obszarów przemysłowych od południa przylega cywilne lotnisko 
Tab. 2. Struktura użytkowania gruntów w Krośnie, Przemyślu i Tarnobrzegu w 2018 r. [w ha] (opracowanie własne na podstawie SUiKZP Krosna 2016, SUiKZP Przemyśla 2017, SUiKZP Tarnobrzega 2017, MPZP Krosna, MPZP Przemyśla, MPZP Tarnobrzega, GUS, OSM, www.mapy.geoportal. gov.pl, www.gis.umkrosno.pl, www.przemysl.geoportal2.pl, www.tarnobrzeg.geoportal2.pl) Table 2. Land use structure in Krosno, Przemyśl and Tarnobrzeg in 2018 [in ha] (own elaboration based on SUiKZP of Krosno 2016, SUiKZP of Przemyśl 2017, SUiKZP of Tarnobrzeg 2017, MPZP of Krosno, MPZP of Przemyśl, MPZP of Tarnobrzeg, GUS, OSM, www.mapy.geoportal.gov.pl, www.gis.umkrosno.pl, www.przemysl. geoportal2.pl, www.tarnobrzeg.geoportal2.pl)

\begin{tabular}{|c|c|c|c|c|c|c|c|c|c|}
\hline Miasto & 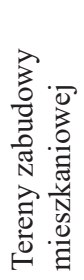 & 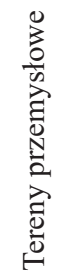 & $\begin{array}{l}\frac{50}{D} \\
\frac{\vec{D}}{\tilde{D}^{n}}\end{array}$ & 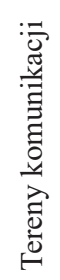 & 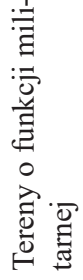 & 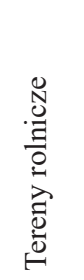 & $\begin{array}{l}\overrightarrow{2} \\
\overrightarrow{0}\end{array}$ & 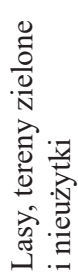 & 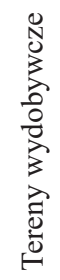 \\
\hline Krosno & 2162 & 242 & $230 *$ & 528 & - & 1045 & 51 & 300 & 20 \\
\hline Przemyśl & 1930 & 253 & $732 *$ & 421 & 45 & 392 & 72 & 1560 & 100 \\
\hline Tarnobrzeg & 1108 & 163 & $382 *$ & 404 & - & 2851 & 776 & 3506 & - \\
\hline
\end{tabular}

* usługi mogą stanowić część terenów zabudowy mieszkaniowej lub przemysłowej

* services can be a part of residential or industrial development areas

powstałe w 1932 r. Dodatkowo funkcjonuje pięć skupisk zabudowy mieszkaniowej na obszarach dzielnic Polanka (w części zachodniej), Zawodzie (północno-wschodniej), Krościenko Niżne (wschodniej) i Suchodół (południowej) oraz osiedla Turaszówka (północno-zachodniej), z tego trzy powstałe w wyniku rozszerzania granic administracyjnych (Turaszówka, Krościenko Niżne i Suchodół). Tereny rolnicze i zielone położone są na peryferiach Krosna przy granicach administracyjnych miasta (ryc. 6).

W przypadku Przemyśla istotną rolę w kształtowaniu struktury funkcjonalno-przestrzennej odgrywa rzeka San, która dzieli miasto na część prawo- i lewobrzeżną. Zabudowa mieszkaniowa skupia się w historycznie ukształtowanej centralnej części miasta. Rozciąga się na zachód i wschód wzdłuż Sanu oraz drogi krajowej nr 28 (DK28), prowadzącej do polsko-ukraińskiego przejścia granicznego w Medyce oraz drogi wojewódzkiej nr 884 (DW884), a także w kierunku północnym wzdłuż drogi krajowej nr 77 (DK77). Ponadto funkcjonuje kilka osiedli zabudowy jednorodzinnej (na północy są to Lipowica i Krakowskie, na zachodzie-Prałkowce, Kruhel Wielki i Zielonka, na południu - Herbutów, a na wschodzie - Przekopana), których usytuowanie dostosowane jest do rzeźby terenu. Obszary przemysłowe rozmieszczone są głównie w południowo-wschodniej części Przemyśla, w dzielnicach Lwowskie i Za Wiarem (na terenach zagrożonych powodzią). Ich lokalizacja związana jest z przebiegiem głównych ciągów komunikacyjnych: DK28 i magistrali 


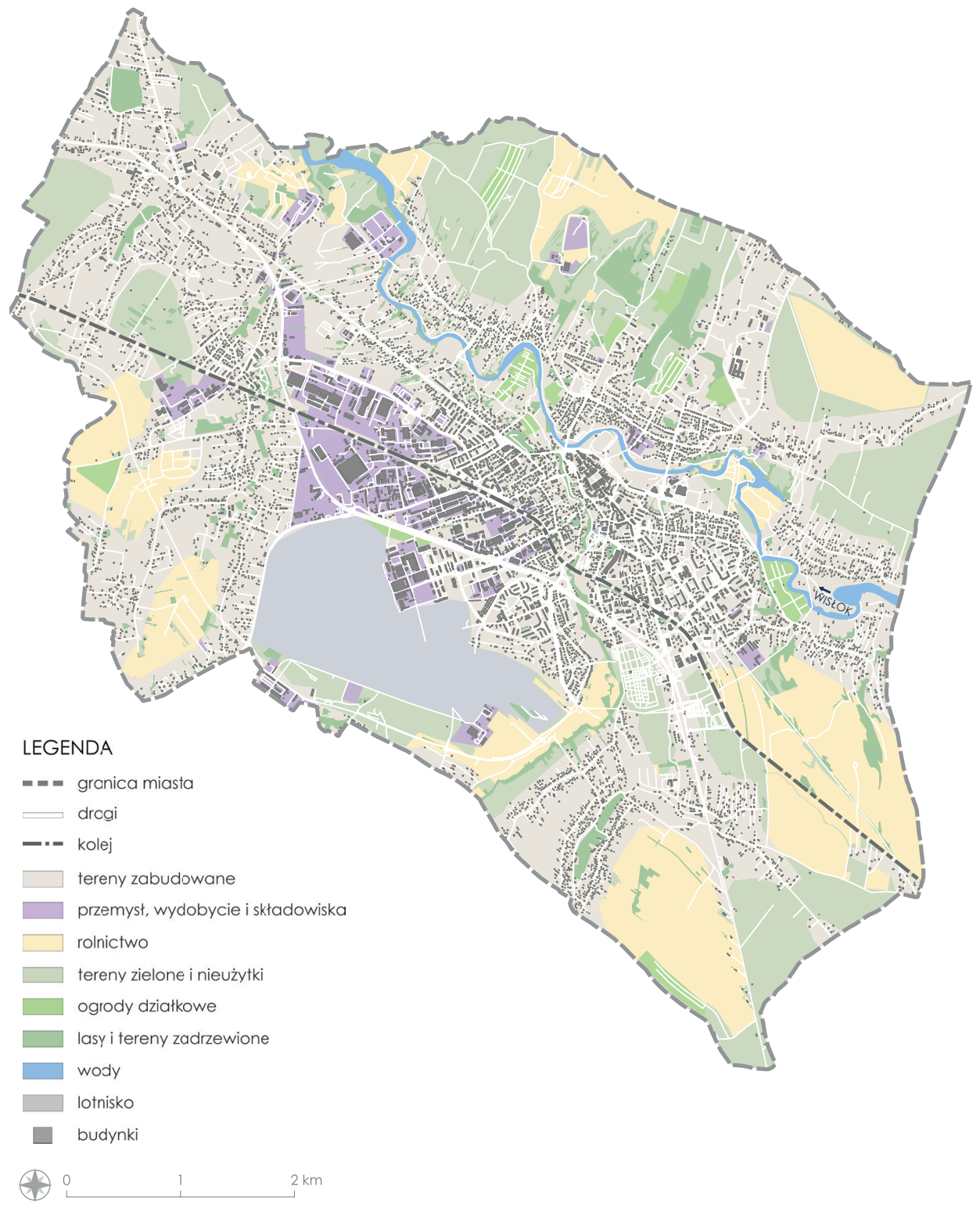

Ryc. 6. Struktura użytkowania gruntów w Krośnie (opracowanie własne na podstawie GUGiK, GDOŚ, OSM, SUiKZP Krosna)

Fig. 6. Land use structure in Krosno (own elaboration based on GUGiK, GDOŚ, OSM, SUiKZP of Krosno)

kolejowej E-30 oraz DW885 i linii kolejowej do Malhowic. Znajduje się tu m.in. podstrefa Tarnobrzeskiej Specjalnej Strefy Ekonomicznej (TSSE) Euro-Park Wisłosan. Pozostałości Twierdzy Przemyśl (forty, szańce, baterie, prochownie) 
zlokalizowane są wokół centrum miasta. Tereny rolnicze znajdują się na wschodzie i przylegają do granicy administracyjnej miasta. Tereny zielone i lasy zajmują część północno-zachodnią oraz południowo-zachodnią miasta (ryc. 7). Część stanowią obszary przyrodniczo cenne, objęte ochroną. Znajdują się one w większości na obszarze przyłączonym w 2009 r. do osiedla Kruhel Wielki.

Tarnobrzeg - w porównaniu do Krosna i Przemyśla - nie posiada historycznie ukształtowanego centrum. Tereny zabudowy mieszkaniowej wielorodzinnej z usługami znajdują się w obrębie centralnej części miasta (obejmują dzielnice Stare Miasto, Serbinów, Wielopole i Siarkowiec). Dodatkowo funkcjonuje osiem osiedli zabudowy mieszkaniowej jednorodzinnej oddzielonych od siebie kompleksami lasów, terenów zielonych i obszarów rolniczych, stanowiących dawne centra wsi przyłączanych do Tarnobrzega w XX w. (do tej pory nazywane są

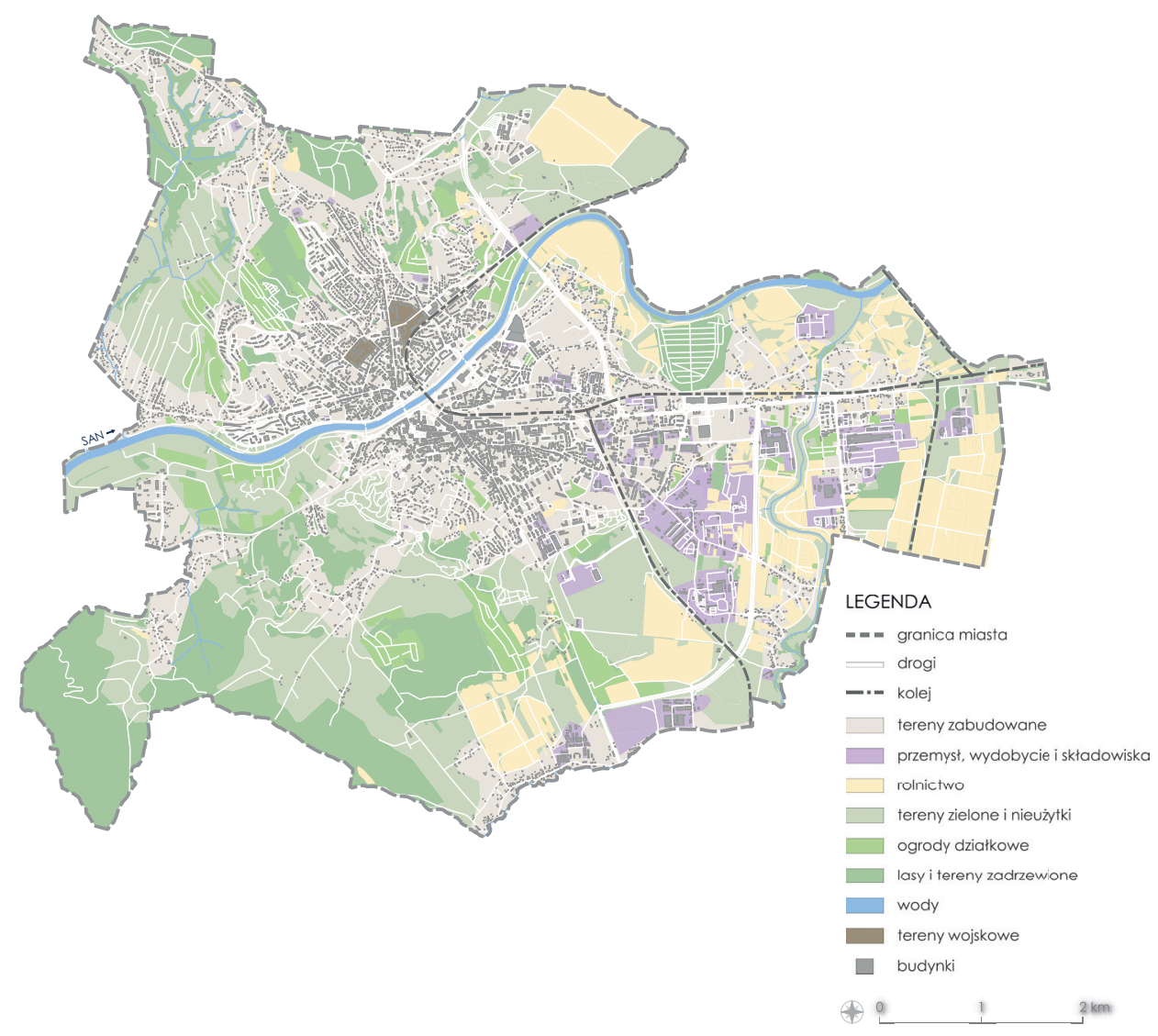

Ryc. 7. Struktura użytkowania gruntów w Przemyślu (opracowanie własne na podstawie GUGiK, GDOŚ, OSM, SUiKZP Przemyśla)

Fig. 7. Land use structure in Przemyśl (own elaboration based on GUGiK, GDOŚ, OSM, SUiKZP of Przemyśl) 
one osiedlami rolniczymi). Usytuowane są one na północ (Wielowieś, Sielec, Sobów, Zakrzów), wschód (Mokrzyszów) oraz południe (Miechocin, Nagnajów, Ocice) od centrum Tarnobrzega. Ten układ zabudowy nadal odzwierciedla proces powiększania granic miasta. W południowej części Tarnobrzega znajdują się tereny przemysłowe (m.in. Tarnobrzeska SSE Euro-Park Wisłosan) oraz

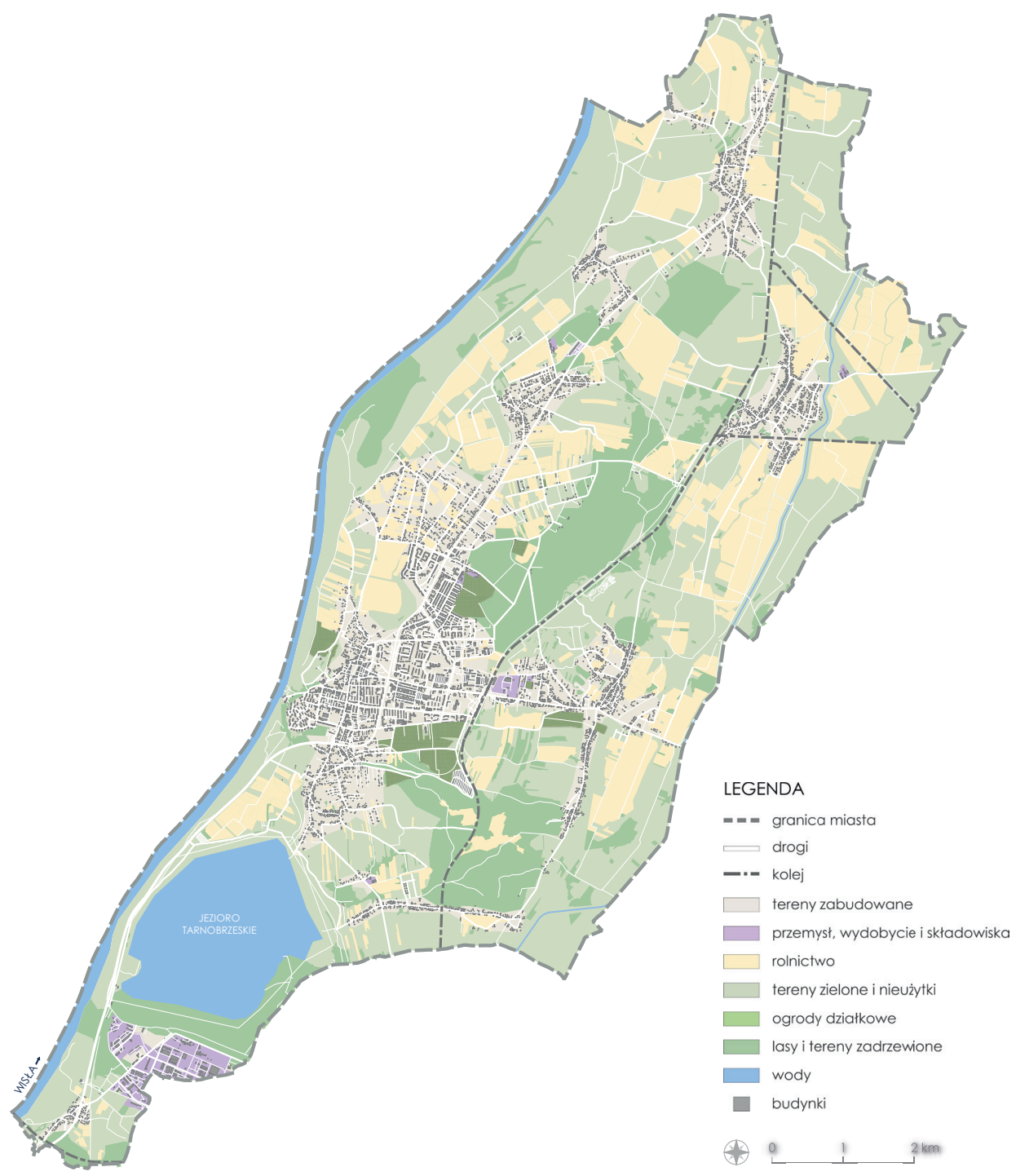

Ryc. 8. Mapa struktury użytkowania gruntów w Tarnobrzegu (opracowanie własne na podstawie GUGiK, GDOŚ, OSM, SUiKZP Tarnobrzega)

Fig. 8. Map of land use structure in Tarnobrzeg (own elaboration based on GUGiK, GDOŚ, OSM, SUiKZP of Tarnobrzeg) 
obszary poeksploatacyjne, w tym sztuczny zbiornik wodny Jezioro Tarnobrzeskie (ryc. 8). Akwen ma ok. 460 ha powierzchni i został utworzony w dawnym wyrobisku kopalni siarki (Szmuc, Madej 2011). Zachodnia granica administracyjna jednostki przebiega wzdłuż rzeki Wisły. Tarnobrzeg posiada wiele naturalnych barier rozwojowych, w tym rzekę oraz rozległe tereny zalewowe (ryc. 2). Są one w znacznej części objęte ochroną w ramach obszarów Natura 2000.

Rozpatrując strukturę funkcjonalno-przestrzenną w kontekście procesów integracji zabudowy i zagospodarowania terenów przyłączonych w wyniku procesu rozszerzenia granic administracyjnych, można zauważyć, że najpełniej występuje ona w Krośnie. W Przemyślu nadal widoczne jest dostosowanie zabudowy i zagospodarowania terenu do warunków naturalnych. W przeciwieństwie do Krosna i Przemyśla w Tarnobrzegu wciąż funkcjonują rozproszone skupiska zabudowy odzwierciedlające układ dawnych wsi włączonych w granice administracyjne miasta w XX w. Rozwój przestrzenny miasta nie był na tyle dynamiczny, aby doszło do ich połączenia. W związku z tym Tarnobrzeg posiada najwięcej rezerw terenów pod dalszą rozbudowę. W tym zakresie mniej korzystną sytuację mają Krosno (enklawy terenów wolnych znajdują się tylko na obrzeżach miasta) i Przemyśl (południowo-wschodnią część miasta zajmują tereny zagrożone powodzią, dodatkowo występują obszary narażone na erozję i ruchy masowe oraz rozległe kompleksy leśne częściowo objęte ochroną). W kontekście prowadzenia efektywnej polityki przestrzennej bardzo istotną kwestią jest uwzględnienie tych potencjałów i ograniczeń w zapisach dokumentów planistyczno-strategicznych analizowanych miast, co omówiono w kolejnej części pracy.

\section{Rozwój jednostek w świetle dokumentów planistyczno-strategicznych}

Z zapisów obowiązujących dokumentów planistycznych wynika, że władze miast prowadzą zróżnicowaną politykę przestrzenną. W Krośnie docelowo wszystkie tereny rolnicze mają być przeznaczone pod funkcję mieszkaniową (56\% powierzchni miasta, wzrost o 9 p.p.), usługową (10\%, 5 p.p.) oraz przemysłową $(16 \%, 11$ p.p.) (tab. 3). Ponadto planuje się rozszerzenie dotychczasowej strefy zabudowy oraz utworzenie trzech nowych zespołów, w tym jednego przemysłowo-usługowego w północnej części miasta (Białobrzegi) oraz dwóch mieszkalnych - na północnym wschodzie (Zawodzie) oraz południowym wschodzie Krosna (Suchodół) (SUiKZP Krosna 2016). Na terenach lotniska Iwonicz docelowo mają powstać m.in. łącznik do drogi S19 i nowa strefa inwestycyjna.

W Przemyślu planuje się dalszą ekspansję przestrzenną w obrębie ścisłego centrum miasta. Część obszarów rolniczych ma zostać zagospodarowana pod przemysł i składy ( $5 \%$ powierzchni miasta, wzrost o 1 p.p.) oraz zabudowę mieszkaniową (38\%, 3 p.p.) (tab. 3). Nowe tereny mieszkaniowe zaplanowano 
na północy miasta na obszarze osiedli Krakowskie, Winna Góra, Lipowica i Warneńczyka, a nowa zabudowa przemysłowa powstanie w obrębie obecnie istniejącej strefy ekonomicznej w południowo-wschodniej części Przemyśla (SUiKZP Przemyśla 2017).

Centrum Tarnobrzega będzie rozwijać się w kierunku północnym, gdzie planowana jest budowa drogi krajowej nr 74 (DK74). Przewiduje się wzrost udziału terenów pod zabudowę mieszkaniową (19\% powierzchni miasta, wzrost o 7 p.p.), przemysłową (9\%, 7 p.p.) i usługową (18\%, 14 p.p.) (tab. 3). Planuje się dalszy rozwój osiedli zabudowy jednorodzinnej, specjalnej strefy ekonomicznej w południowej części miasta oraz terenów rekreacyjnych położonych przy Jeziorze Tarnobrzeskim. Dodatkowo powstaną trzy nowe skupiska zabudowy mieszkaniowej wielo- i jednorodzinnej oraz nowe centra przemysłowe na północno-wschodnim obszarze miasta, w obrębie osiedli Sobów, Wielowieś i Sielec (SUiKZP Tarnobrzega 2017), w sąsiedztwie planowanej DK74.

Tab. 3. Kierunki zmian w strukturze użytkowania gruntów Krosna, Przemyśla i Tarnobrzega [w ha] (opracowanie własne na podstawie SUiKZP Krosna 2016, SUiKZP Przemyśla 2017, SUiKZP Tarnobrzega 2017, MPZP Krosna, MPZP Przemyśla, MPZP Tarnobrzega, GUS, OSM, www.mapy.geoportal.gov.pl, www.gis.umkrosno.pl, www.przemysl.geoportal2.pl, www.tarnobrzeg.geoportal2.pl) Table 3. Directions of changes in the land use structure of Krosno, Przemyśl and Tarnobrzeg [in ha] (own elaboration based on SUiKZP of Krosno 2016, SUiKZP of Przemyśl 2017, SUiKZP of Tarnobrzeg 2017, MPZP of Krosno, MPZP of Przemyśl, MPZP of Tarnobrzeg, GUS, OSM, www.mapy.geoportal.gov.pl, www.gis.umkrosno. pl, www.przemysl.geoportal2.pl, www.tarnobrzeg.geoportal2.pl)

\begin{tabular}{|c|c|c|c|c|c|c|c|c|c|}
\hline Miasto & 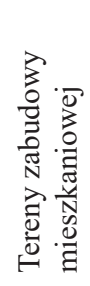 & 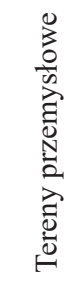 & $\begin{array}{l}\overrightarrow{50} \\
\frac{\vec{E}}{\omega}\end{array}$ & 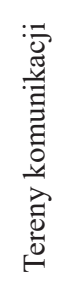 & 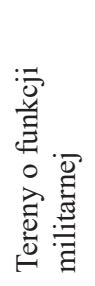 & 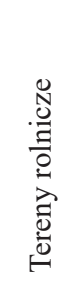 & $\begin{array}{l}\overrightarrow{7} \\
\dot{3}\end{array}$ & 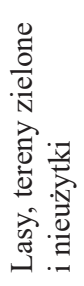 & 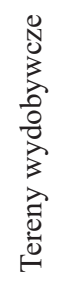 \\
\hline Krosno & 2946 & $814 *$ & $514 *$ & 650 & - & - & 51 & 280 & 20 \\
\hline Przemyśl & 2096 & 293 & $847 *$ & 451 & 45 & 195 & 72 & 1533 & 100 \\
\hline Tarnobrzeg & 1733 & $845^{*}$ & $1548^{*}$ & 504 & - & 2189 & 776 & 1468 & - \\
\hline
\end{tabular}

* tereny mogą stanowić część zabudowy mieszkaniowej, usługowej bądź przemysłowej

* the areas can be a part of residential, commercial or industrial development

Z przeglądu zamieszczonego w tab. 3 wynika, że wszystkie miasta planują zwiększenie terenów pod zabudowę mieszkaniową (nie znajduje to odzwierciedlenia w danych demograficznych), a także stawiają na rozwój przemysłu, przy czym najsilniej Krosno, które posiada rezerwę terenów inwestycyjnych w postaci lotniska Iwonicz. Należy też dodać, że planowy rozwój miast 
będzie się odbywał w większości w nawiązaniu do już istniejącej struktury funkcjonalno-przestrzennej.

\section{Miejskie obszary funkcjonalne ośrodków subregionalnych}

Istotną rolę $\mathrm{w}$ rozwoju analizowanych miast odgrywają ich obszary funkcjonalne. Zgodnie z podziałem przyjętym w Koncepcji Przestrzennego Zagospodarowania Kraju 2030 (2011), który znalazł odzwierciedlenie w Planie Zagospodarowania Przestrzennego Województwa Podkarpackiego (2015), w województwie podkarpackim funkcjonuje sześć miejskich obszarów funkcjonalnych ośrodków subregionalnych, w tym m.in. krośnieński, przemyski i tarnobrzeski.

MOF Krosna obejmuje Krosno (rdzeń) oraz sześć gmin, w tym jedną gminę miejsko-wiejską Jedlicze i pięć gmin wiejskich: Chorkówkę, Korczynę, Krościenko Wyżne, Miejsce Piastowe, Wojaszówkę (ryc. 9). MOF Krosna zajmuje powierzchnię $423 \mathrm{~km}^{2}$ i zamieszkuje go 115469 mieszkańców. Obszar miasta stanowi $10 \%$ całego MOF oraz $40 \%$ jego ludności. MOF Krosna charakteryzuje wysoka gęstość zaludnienia $\left(272 \mathrm{os} . / \mathrm{km}^{2}\right)$, dodatni przyrost naturalny ( 0,61 os. na 1000 mieszkańców) oraz ujemne saldo migracji ( $-0,9$ os. na 1000 mieszkańców). Tereny zurbanizowane zlokalizowane są przy granicach administracyjnych Krosna (miejscowości: Głowienka, Korczyna, Krościenko Wyżne, Potok, Świerzowa Polska, Miejsce Piastowe, Łężany). Są to miejscowości rolnicze, z niewielkim udziałem zabudowy przemysłowej i usługowej (wyjątek stanowi Jedlicze, w którym znajdują się rafineria i huta szkła). Tworzą one spójny układ przestrzenny o charakterze pasmowo-policentrycznym. Zabudowa skupia się w sąsiedztwie dróg DK28 i DK19 oraz DW990 i DW991, które stanowią osie rozwojowe tego obszaru funkcjonalnego.

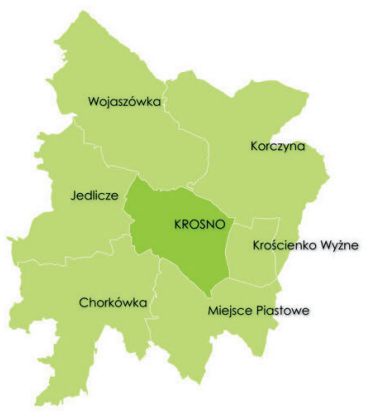

MOF KROSNA

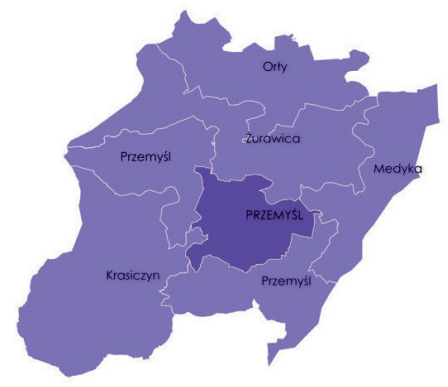

MOF PRZEMYŚLA

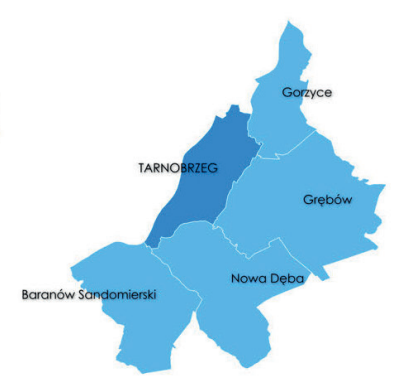

MOF TARNOBRZEGA

Ryc. 9. Miejskie obszary funkcjonalne Krosna, Przemyśla i Tarnobrzega (opracowanie własne na podstawie GUGiK i PZPWP 2030)

Fig. 9. Functional urban areas of Krosno, Przemyśl and Tarnobrzeg (own elaboration based on GUGiK and PZPWP 2030) 
Miejski Obszar Funkcjonalny Przemyśla obejmuje - poza miastem centralnym - pięć gmin wiejskich: Krasiczyn, Żurawica, Medyka, Przemyśl i Orły, przy czym ostatnia $\mathrm{z}$ nich jako jedyna nie sąsiaduje bezpośrednio $\mathrm{z}$ miastem (ryc. 9). MOF Przemyśla zajmuje $505 \mathrm{~km}^{2}$ powierzchni i liczy ponad 107 tys. mieszkańców (gęstość zaludnienia 209,3 os. $/ \mathrm{km}^{2}$ ). Obszar miasta stanowi 9\% całego MOF oraz 58\% jego ludności. MOF Przemyśla charakteryzuje dodatni przyrost naturalny ( 0,74 os. na 1000 mieszkańców), a także dodatnie saldo migracji (0,3 os. na 1000 mieszkańców). Tereny zurbanizowane są rozproszone na całym obszarze jednostki. Bezpośrednio z miastem graniczy tylko kilka miejscowości (od zachodu - Prałkowce, Ostrów i Kuńkowce, od południa - Pikulice, Nehrybka i Krówniki, od północnego-wschodu - Buszkowice). Są to w większości miejscowości rolnicze oddzielone od siebie kompleksami lasów oraz silnie meandrującą rzeką San. Zabudowa skupia się w sąsiedztwie dróg DK28 i DK77 oraz DW885, DW884 i DW881, tworząc układy pasmowo-policentryczne z dominacją zabudowy mieszkaniowej.

W zasięg MOF Tarnobrzega wchodzą - oprócz miasta centralnego - dwie gminy miejsko-wiejskie: Baranów Sandomierski i Nowa Dęba, oraz dwie gminy wiejskie: Grębów i Gorzyce (ryc. 9). MOF Tarnobrzega ma powierzchnię $606 \mathrm{~km}^{2}$ i ponad 102 tys. mieszkańców (z czego ośrodek rdzeniowy zajmuje 14\% obszaru, a jego ludność stanowi 51\%) oraz posiada najniższą gęstość zaludnienia spośród trzech analizowanych obszarów funkcjonalnych $\left(155,2 \mathrm{os} . / \mathrm{km}^{2}\right)$. Charakteryzuje go dodatni przyrost naturalny ( 0,28 os. na 100 mieszkańców) i ujemne saldo migracji (-2,84 os. na 1000 mieszkańców). MOF Tarnobrzega ma charakter rolniczo-przemysłowy, a skupiska zabudowy są oddzielone rozległymi kompleksami leśnymi i obszarami rolniczymi. Znajdują się tu miejscowości z rozwiniętym przemysłem (Gorzyce, Chmielów, Nowa Dęba), wokół których w ostatnich latach obserwuje się ekspansję zabudowy jednorodzinnej i nasilenie procesów suburbanizacji. To sprawia, że system osadniczy tego obszaru funkcjonalnego nabiera cech układu policentrycznego. Jego osiami są drogi DK9, DK77, DW871, DW872 i DW985 oraz linie kolejowe 25 i 71. MOF Tarnobrzega sąsiaduje od zachodu z MOF Mielca, a od wschodu graniczy bezpośrednio z MOF Stalowej Woli, co stawiało go w obliczu konkurencji z silnymi ośrodkami przemysłowymi. Ostatnio wizja rozwoju tego terytorium uległa znaczącej zmianie. Z inicjatywy władz Tarnobrzega konkurencja zaczyna się przeradzać w kooperację. W kwietniu 2019 r. włodarze Tarnobrzega, Stalowej Woli, Sandomierza i Niska zawarli umowę o nawiązaniu partnerskiej współpracy, tworząc w ten sposób unikalną w skali kraju nową strukturę terytorialną i zarządczą o nazwie Czwórmiasto, obejmującą obszar 2 województw, 5 powiatów i 27 gmin (Wojtkowiak, 2020). Obecnie trwają prace nad opracowaniem strategii rozwoju tego obszaru. 
Mimo wielu podobieństw obszary funkcjonalne charakteryzowanych miast różnią się od siebie. Miejscowości leżące w granicach MOF Krosna tworzą spójny układ przestrzenny. Obszar ten jest najgęściej zabudowany spośród wszystkich tu omawianych. Na terenie obszarów funkcjonalnych Krosna i Tarnobrzega usytuowane są prężnie rozwijające się ośrodki przemysłowe, co nie występuje w obrębie MOF Przemyśla. Biorąc pod uwagę sytuację demograficzną, należy zauważyć, że największe odpływy ludności występują w przypadku MOF Tarnobrzega, co w dalszej perspektywie może skutkować depopulacją tego obszaru oraz umacnianiem policentryczności struktury osadniczej. Najkorzystniejszą sytuację odnotowano w MOF Przemyśla (dodatni przyrost naturalny i saldo migracji). Uwzględniając rolniczy charakter obszaru, warunki naturalne i znaczny udział obszarów chronionych, trzeba stwierdzić, że zmiany przestrzenne będą tu zachodzić raczej w kierunku wzmocnienia i dogęszczenia już istniejących struktur. W przyszłości może dojść do zagęszczenia zabudowy wzdłuż drogi DW885 w kierunku nowego przejścia granicznego Malhowice-Niżankowice.

\section{KSZTAŁTOWANIE UKŁADÓW PRZESTRZENNYCH MIAST PO 1989 R.}

\section{Krosno}

Krosno w 1989 r. było ważnym ośrodkiem przemysłu szklarskiego i lotniczego oraz stanowiło centrum zagłębia naftowego kraju. Dodatkowo jego położenie przy granicy z Czechosłowacją czyniło je istotnym punktem wymiany handlowej. Od 1992 r. następuje spadek liczby mieszkańców (www.stat.gov.pl). Po reformie administracyjnej z 1998 r. rozwój Krosna uległ zahamowaniu. Przełom nastąpił w 2011 r., kiedy utworzono w zachodniej części Krosna podstrefę SSE Euro-Park Mielec, a następnie filię Krakowskiego Parku Naukowo-Technologicznego, zwiększając tym samym udział terenów przemysłowych poprzez sukcesję funkcjonalną na obszary rolnicze. Spośród analizowanych miast Krosno rozwija się najszybciej, co potwierdzają dane dotyczące zarówno rynku pracy, jak i poziomu przedsiębiorczości (Tokarski i in. 2012; www.bdl.stat.gov.pl). Zachowało ono status ważnego w skali kraju ośrodka szklarskiego, a lokalne władze starają się o przywrócenie funkcji lotniczej. Na przyłączonych terenach lotniska Iwonicz planowana jest budowa łącznika drogi S19, która połączy miasto z autostradą A4, a także rozbudowa zaplecza przemysłowego.

Krosno obecnie rozwija się w układzie policentryczno-pasmowym. Miasto posiada jeden główny ośrodek z zabudową mieszkaniową śródmiejską, który stanowi centrum jednostki. Na zachód od strefy śródmiejskiej zlokalizowane zostały tereny inwestycyjne i przemysłowe, a na południu znajduje się lotnisko. 
Zabudowa podmiejska rozciąga się w kierunku północno-zachodnim i południowo-wschodnim wzdłuż rzeki Wisłok oraz głównych ciągów komunikacyjnych, tj. linii kolejowej nr 108 oraz dróg DK28 i DW991, które stanowią osie rozwojowe miasta. Dodatkowo w Krośnie funkcjonuje kilka skupisk zabudowy jednorodzinnej, które są efektem poszerzania granic miasta (Suchodół, Białobrzegi, Krościenko Niżne, Turaszówka) (ryc. 10).

Zapisy Studium uwarunkowań i kierunków zagospodarowania przestrzennego miasta Krosna (2016) pokrywają się z prezentowanym modelem rozwojowym. Zgodnie z założeniami dokumentu miasto zostało podzielone na strefę centrum, strefę śródmiejską oraz strefę urbanizowaną. Dla wydzielonych stref określono wiodące funkcje i kierunki rozwoju. Pierwsza z nich ma chronić istniejący zespół staromiejski. Na obszarze strefy śródmiejskiej planuje się dalszy rozwój funkcji mieszkaniowej i rekreacyjnej. Obie strefy łącznie stanowią główne centrum miasta (ryc. 10). Strefa zurbanizowana obejmuje tereny zabudowy jednorodzinnej i produkcyjnej oraz nieużytki. Docelowo cały ten obszar ma zostać zabudowany. Ponadto dokument zakłada utworzenie centrów wspomagających, które mają przyczynić się do poprawy jakości życia mieszkańców ze względu na wyznaczenie na ich obszarach nowych terenów usługowych. Znajdują one odzwierciedlenie w położonych na obrzeżach Krosna dzielnicach, których lokalizacja jest wynikową procesu rozszerzania granic miasta (por. ryc. 3).

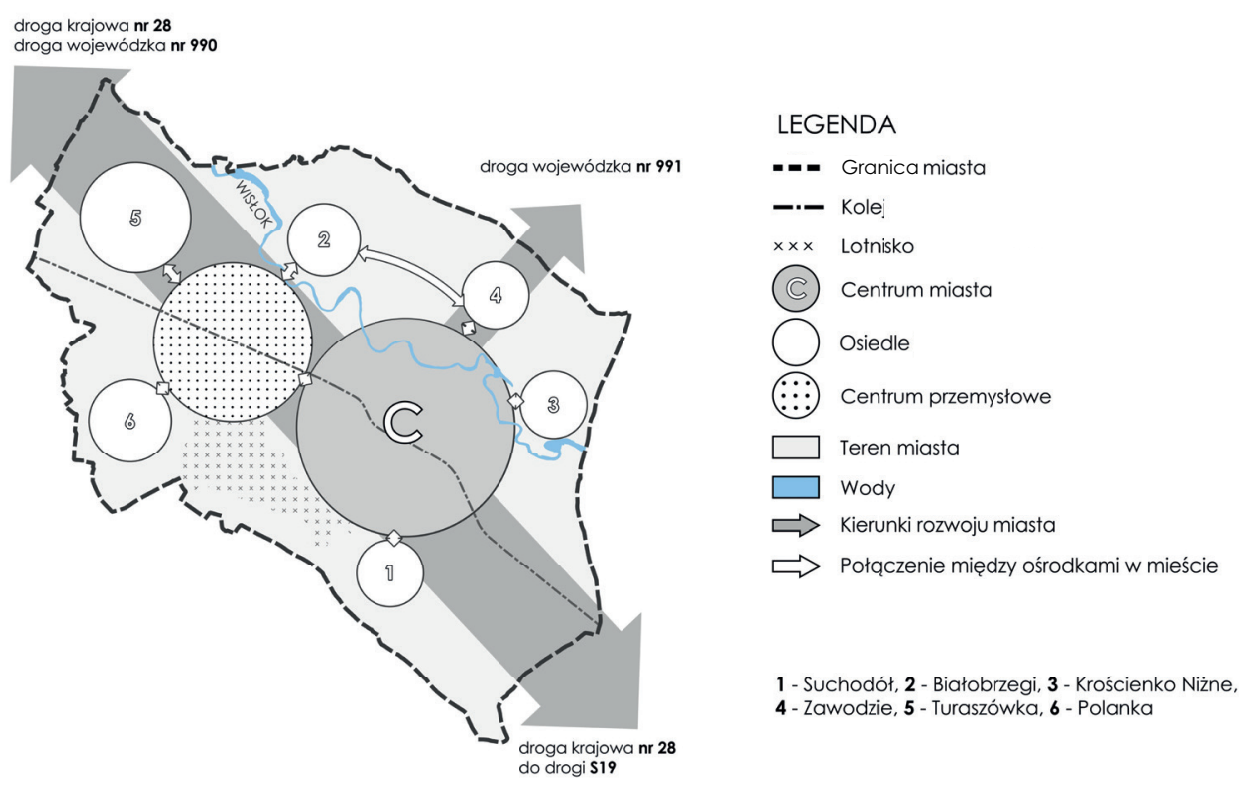

Ryc. 10. Model rozwoju przestrzennego Krosna (opracowanie własne)

Fig. 10. Spatial development model of Krosno (own elaboration) 


\section{Przemyśl}

Przemyśl jest ważnym ośrodkiem transgranicznym leżącym przy wschodniej granicy Polski i Unii Europejskiej oraz stanowi główny punkt wymiany handlowej z Ukrainą. Przez miasto przebiegają ważne szlaki komunikacyjne, m.in. drogi DK28 i DK77, łączące miasto z autostradą A4, oraz magistrala kolejowa E-30, biegnąca z Europy Zachodniej na Wschód. Dodatkowo miasto jest ważnym ośrodkiem militarnym, historycznym i turystycznym. Od lat 90. XX w. Przemyśl przestał się intensywnie rozwijać. Główną przyczyną było stałe uszczelnianie granicy z Ukrainą, co negatywnie wpłynęło na lokalną gospodarkę (Tokarski i in. 2012; Tomaszewski 2019). Ważnymi stymulantami rozwoju miasta były m.in. otwarcie podstrefy TSSE Euro-Park Wisłosan w 2006 r., którą zlokalizowano we wschodniej części miasta, a także budowa kluczowego w skali kraju odcinka autostrady A4 Jarosław-Przemyśl-Korczowa. Obecnie pozycja miasta zaczęła stopniowo wzrastać ze względu na prowadzoną politykę transportową i gospodarczą państwa oraz złagodzenie przepisów dotyczących obsługi ruchu przygranicznego z Ukrainą.

Strukturę przestrzenną Przemyśla charakteryzuje układ koncentryczno-pasmowy. Obszar staromiejski jest skupiskiem działalności administracyjnej, usługowej i handlowej. Jest to reprezentacyjna część ośrodka z licznymi atrakcjami turystycznymi, która w 2018 r. wraz z kompleksem Twierdzy Przemyśl została wpisana na listę pomników historii. Następną strefę przejściową tworzy zabudowa śródmiejska o gorszym standardzie technicznym. Na jej terenie występuje duża liczba mieszkań komunalnych. Kolejną strefą miasta, położoną głównie na terenach prawobrzeżnych, jest obszar blokowisk powstałych na przełomie lat 50. i 60. XX w. Strefa zabudowy staromiejskiej i śródmiejskiej oraz blokowiska tworzą ścisłe centrum Przemyśla. Ostatnią strefę peryferyjną stanowią odosobnione skupiska zabudowy jednorodzinnej (na północy osiedla - Lipowica i Budy Wielkie, na zachodzie - Prałkowce, Kruhel Wielki i Zielonka, na południu - Herbutów, a na wschodzie - Przekopana), których rozmieszczenie jest dostosowane do rzeźby terenu. W Przemyślu tereny przemysłowe zlokalizowane zostały w południowo-wschodniej części miasta przy ciągu komunikacyjnym biegnącym do przejścia granicznego w Medyce. Główne centrum rekreacyjne znajduje się w obrębie Kopca Tatarskiego położonego w południowo-zachodniej części miasta. Miasto posiada cztery osie rozwojowe. Główna z nich przebiega na linii wschód-zachód, tj. wzdłuż drogi DK28 i magistrali kolejowej E30 do przejścia granicznego w Medyce oraz wzdłuż Sanu w kierunku miejscowości Prałkowce i Ostrów (skupiska zabudowy podmiejskiej). Północną oś rozwojową wyznacza droga DK77 biegnąca do autostrady A4. Oś o najmniejszej sile oddziaływania przebiega na południe równolegle do drogi DW885 przez strefę 

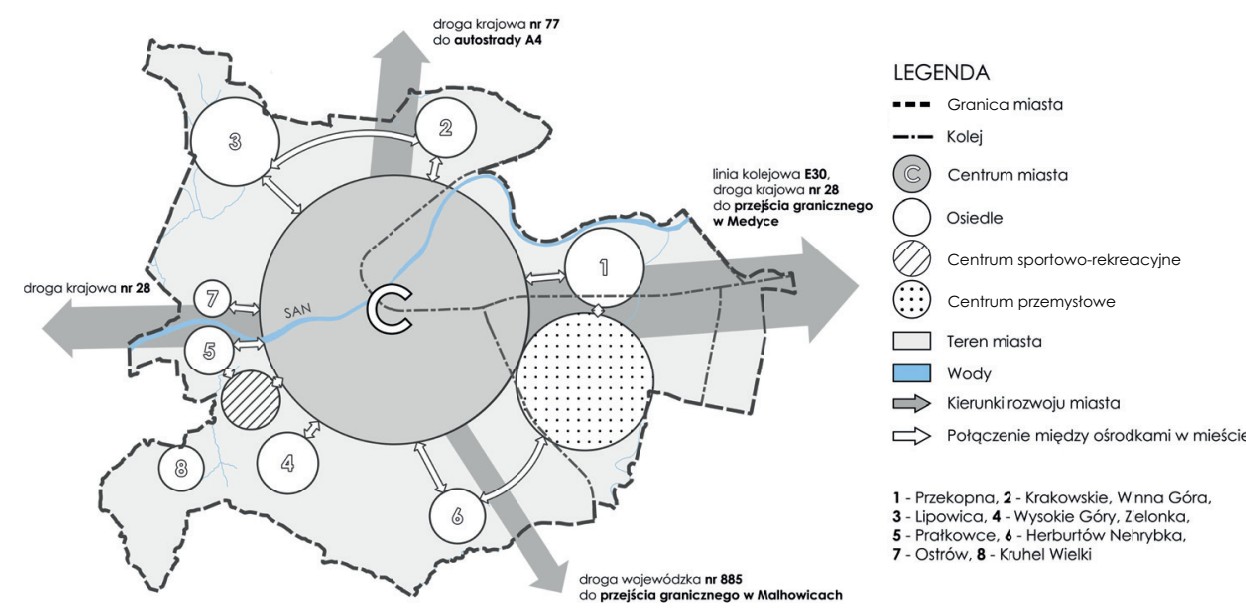

Ryc. 11. Model rozwoju przestrzennego Przemyśla (opracowanie własne)

Fig. 11. Spatial development model of Przemyśl (own elaboration)

ekonomiczną do nowego drogowego i pieszego przejścia granicznego Malhowice-Niżankowice (ryc. 11), które ma odciążać ruch na przejściu granicznym w Medyce. Jego oddanie może przyczynić się w przyszłości do wzrostu znaczenia tej osi rozwojowej (SUiKZP Przemyśla 2017).

Zapisy dokumentów planistycznych i strategicznych Przemyśla są zgodne z przedstawionym modelem rozwojowym miasta i przewidują rozbudowę już istniejących struktur funkcjonalno-przestrzennych. Studium uwarunkowań i kierunków zagospodarowania przestrzennego miasta Przemyśla (2017), podobnie jak w przypadku Krosna, dzieli miasto na strefy. Są to: stare miasto, śródmieście, ogólnomiejska, park sportowo-rekreacyjny i Twierdza Przemyśl. Obszary stare miasto i śródmieście stanowią centrum miasta. Stare miasto jest rdzeniem rozwojowym, a śródmieście - strefą przejściową do terenu blokowisk i peryferii miasta. Park sportowo-rekreacyjny usytuowany jest w południowo-zachodniej części miasta na terenie Kopca Tatarskiego.

\section{Tarnobrzeg}

Tarnobrzeg od lat 50. XX w. był głównym ośrodkiem wydobycia siarki w Polsce i jednym z najszybciej rozwijających się miast w kraju (Gawryszewski 2005). Od otwarcia odkrywkowej kopalni siarki „Machów” w 1954 r. miasto trzykrotnie powiększyło swoje terytorium (ryc. 5). W 1992 r. ze względu na nierentowność wydobycia surowca zamknięto kopalnię, co przyczyniło się do znaczącego osłabienia pozycji miasta i zahamowania jego rozwoju. Miało temu zapobiec otwarcie TSSE w 1997 r. na terenach po kopalni Machów 
w sąsiedztwie drogi DK9 (w granicach Tarnobrzega znajduje się wschodnia część obszaru strefy, pozostała leży w obrębie wsi Chmielów). Po reformie administracyjnej z 1998 r. do ważnych wydarzeń można zaliczyć m.in. oddanie do użytku Jeziora Tarnobrzeskiego (2009), powódź miasta w 2010 r., w wyniku której wprowadzono znaczące ograniczenia w powstawaniu nowej zabudowy na terenach zalewowych, a także utworzenie Tarnobrzeskiego Parku Przemysłowo-Technologicznego w Zakrzowie w 2013 r. Tarnobrzeg - pomimo początkowo najlepszej sytuacji gospodarczej oraz posiadania specjalnej strefy ekonomicznej i parku technologicznego - rozwija się najwolniej spośród charakteryzowanych miast. Przyczyną tego jest upadek przemysłu siarkowego, który był głównym „motorem” rozwoju społeczno-gospodarczego miasta.

Tarnobrzeg cechuje się układem policentrycznym. Miasto rozwija się głównie w kierunku północnym i wschodnim. Uwarunkowane jest to bezpośrednim sąsiedztwem z Sandomierzem oraz przebiegiem drogi DW781 w kierunku gminy Grębów oraz Stalowej Woli. Naturalną barierę rozwojową stanowi rzeka Wisła, przez którą w obrębie granic Tarnobrzega funkcjonuje jedynie przeprawa promowa. Dodatkowe ograniczenie na południu ośrodka, mimo przebiegu drogi DK9, stanowi rozległa strefa zalewowa. Szansą na polepszenie dostępności komunikacyjnej dla gmin leżących po zachodniej stronie Wisły jest realizacja planowanej drogi S74 na odcinku Opatów-Nisko wraz z budową mostu na Wiśle, co może przyczynić się również do połączenia rozproszonych skupisk osadniczych. Miasto posiada jeden główny rdzenny ośrodek o funkcji mieszkaniowej i usługowo-handlowej. Stanowi on centrum całej jednostki. Dodatkowo w Tarnobrzegu usytuowanych jest osiem oddzielnych stref zabudowy mieszkaniowej jednorodzinnej (Miechocin, Mokrzyszów, Nagnajów, Ocice, Sielec, Sobów, Wielowieś, Zakrzów), będących pozostałością procesu rozszerzania granic administracyjnych (por. ryc. 5). Tereny przemysłowe i rekreacyjne zlokalizowane są w południowej części miasta w obrębie dawnej kopalni siarki (ryc. 12).

Studium uwarunkowań i kierunków zagospodarowania przestrzennego miasta Tarnobrzega (2017) posiada zbieżne założenia do prezentowanego modelu rozwojowego miasta. Zakłada ono rozwój istniejącej struktury funkcjonalno-przestrzennej, w szczególności poprzez uzupełnianie już istniejącej zabudowy. Docelowo ma zostać ukształtowane jedno główne centrum usługowe o znaczeniu ponadlokalnym. Planuje się również rozwój przestrzenny dawnych wsi włączonych w granice administracyjne miasta, które mają tworzyć podcentra Tarnobrzega. Dodatkowo mają zostać rozbudowane m.in. TSSE, park przemysłowo-technologiczny oraz baza turystyczna nad Jeziorem Tarnobrzeskim. Wszystkie te elementy znajdują odzwierciedlenie w policentrycznym układzie przestrzennym miasta. 


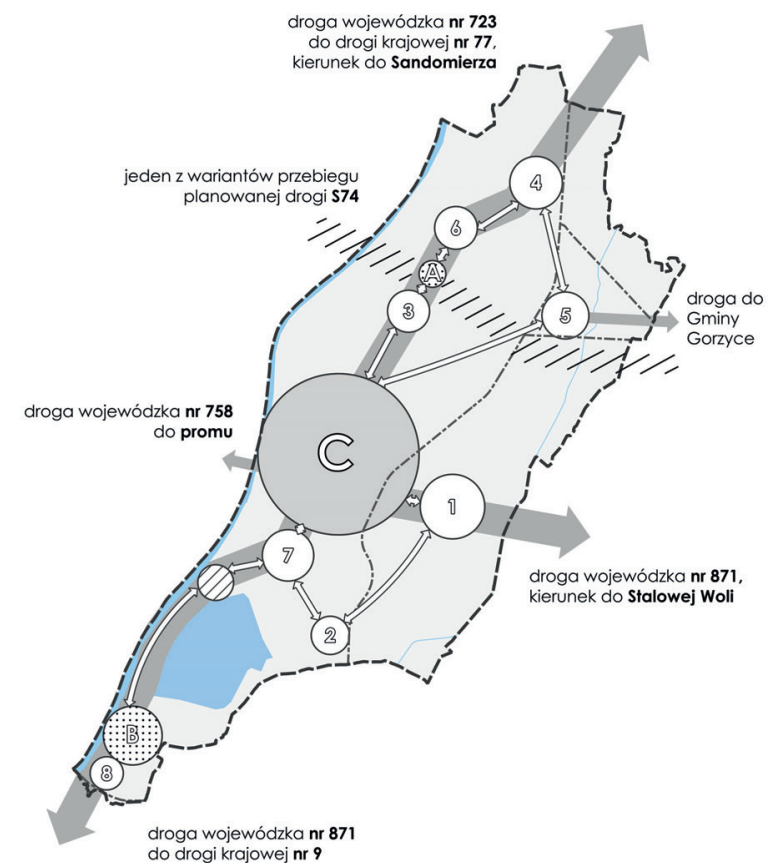

LEGENDA:

--- Granica miasta

-.- Kolej

DA Wariant przebiegu drogi $S 74$

(C) Centrum miasta

$\bigcirc$ Osiedle

Centrum sportowo-rekreacyjne

$\because::$ Centrum przemystowe

Teren miasta

$\square$ Wody

$\Rightarrow$ Kierunki rozwoju miasta

$\Rightarrow$ Połączenie między ośrodkami w mieście

1 - Mokrzyszów, 2 - Ocice, 3 - Zakrzów,

4 - Wielowieś, 5 - Sobów, 6 - Sielec,

7 - Miechocin, 8 - Nagnajów

A - TPP-T

B - TSSE

Ryc. 12. Model rozwoju przestrzennego Tarnobrzega (opracowanie własne)

Fig. 12. Spatial development model of Tarnobrzeg (own elaboration)

\section{ZAKOŃCZENIE}

Praca miała na celu ukazanie uwarunkowań i efektów rozwoju przestrzennego byłych miast wojewódzkich: Tarnobrzega, Krosna i Przemyśla. Prześledzono, jak na rozwój przestrzenny byłych miast wojewódzkich wpłynęły uwarunkowania historyczne, reformy terytorialno-administracyjne i transformacja ustrojowa oraz jakie kierunki rozwojowe wyznaczyły im władze lokalne, co znalazło odzwierciedlenie w modelach rozwojowych tych miast.

Z przeprowadzonych badań wynika, że miasta, które w okres transformacji weszły jako znaczące w skali kraju ośrodki przemysłowe, obecnie posiadają zróżnicowane stymulanty i destymulanty rozwoju przestrzennego. W przypadku Krosna i Przemyśla stymulantami są położenie przygraniczne pozwalające na prowadzenie wymiany handlowej i czerpanie korzyści z ruchu granicznego oraz przebieg ważnych ciągów komunikacyjnych (magistrala kolejowa E30, drogi DK28 i DK77, łączniki do S19 i autostrady A4), które stanowią główne osie rozwojowe tych miast. $\mathrm{Z}$ kolei Tarnobrzeg zmaga się z licznymi barierami naturalnymi (rzeka Wisła, rozległa strefa zalewowa) i infrastrukturalnymi (brak mostu przez Wisłę), które determinują jego rozwój przestrzenny, a na sytuację 
społeczno-gospodarczą wpływa przede wszystkim sąsiedztwo dobrze rozwiniętych ośrodków przemysłowych (Stalowa Wola, Nisko, Sandomierz), z którymi $\mathrm{z}$ inicjatywy władz Tarnobrzega rozpoczęto w ostatnim czasie proces tworzenia nowej struktury zarządczej o nazwie Czwórmiasto.

Rozszerzenia granic administracyjnych analizowanych miast miały miejsce głównie w okresie PRL-u, czyli w czasach dobrej koniunktury gospodarczej i powiązanej z nią szybkiej ekspansji przestrzennej (Tokarski 2012). Co istotne, w przypadku Przemyśla i Krosna przyłączone tereny zostały zagospodarowane i zabudowane (w przypadku Przemyśla widoczne jest dostosowanie zabudowy do warunków terenowych), co spowodowało ukształtowanie się w miarę spójnych układów przestrzennych. Krosno dodatkowo od 2021 r. włączy w swe granice kolejne tereny inwestycyjne po byłym lotnisku Iwonicz. Zupełnie inaczej przedstawia się sytuacja Tarnobrzega, gdzie ponad 50\% obecnej powierzchni miasta przyłączono w XX w. w związku z rozwojem przemysłu siarkowego. Jego upadek w początkach lat 90. przyczynił się do spowolnienia tempa rozwoju gospodarczego i znacznego odpływu ludności, przez co rozwój przestrzenny przyłączonych wsi jest powolny i nadal stanowią one rolnicze enklawy będące rezerwą dla rozbudowy miasta.

Struktura funkcjonalno-przestrzenna analizowanych miast odzwierciedla ich rozwój historyczny, zmiany granic i decyzje lokalizacyjne z okresu gospodarki centralnie sterowanej (Krzysztofik 2014) oraz wykazuje dostosowanie do warunków naturalnych. Znajduje to wyraz w odmiennych układach przestrzennych charakteryzowanych ośrodków. Krosno cechuje układ policentryczno-pasmowy, Przemyśl - koncentryczno-pasmowy, a Tarnobrzeg - policentryczny.

Zapisy dokumentów strategiczno-planistycznych zakładają rozwój przestrzenny miast w nawiązaniu do istniejącej struktury funkcjonalno-przestrzennej oraz osi rozwojowych wyznaczonych przebiegiem linii komunikacyjnych i dolin rzek. Jednakże obecnie prowadzona polityka przestrzenna nie uwzględnia wszystkich uwarunkowań i aspektów rozwojowych. Mimo prognozowanego odpływu ludności władze miast przeznaczają coraz więcej nowych terenów pod zabudowę mieszkaniową kosztem terenów rolniczych i zielonych. Jest to szczególnie widoczne w przypadku Krosna. Należy też zauważyć, że w przyszłości może nastąpić wzmocnienie lub pojawienie się nowych osi rozwojowych, co jest związane z planowanymi inwestycjami drogowymi (Tarnobrzeg), rozszerzeniem granic miasta (Krosno) czy rozbudową infrastruktury przejść granicznych (Przemyśl).

Rozwój przestrzenny miast powinien odbywać się w nawiązaniu do ich miejskich obszarów funkcjonalnych, skupiających w swoim obrębie miejscowości z rozwiniętą funkcją usługowo-przemysłową, dobrze skomunikowane z ośrodkiem rdzeniowym. Sytuacja taka występuje jedynie w przypadku MOF Krosna i MOF Tarnobrzega, który dodatkowo charakteryzuje się policentryczną 
strukturą osadniczą zarówno w skali miasta rdzeniowego, jak i całego obszaru. Z kolei Przemyśl stanowi silne centrum gospodarcze dla rolniczego zaplecza.

Reasumując, władze miast powinny skupić się na uzupełnieniu obecnie istniejących struktur funkcjonalno-przestrzennych oraz podjąć działania w celu przeciwdziałania procesom suburbanizacji, prowadząc politykę przestrzenną uwzględniającą założenia rozwoju miejskich obszarów funkcjonalnych przy wykorzystaniu potencjału jednostek oraz niwelowaniu barier rozwojowych.

\section{BIBLIOGRAFIA}

\section{Literatura}

Bagdziński S.L. 1994. Lokalna polityka gospodarcza w okresie transformacji systemowej. Toruń: Wydawnictwo UMK.

Borsa M. 2008. Polityka przestrzenna w gospodarce regionalnej i lokalnej. W: Z. Strzelecki (red.), Gospodarka regionalna i lokalna (s. 174-196). Warszawa: PWN.

Burgess E.W. 1925. Growth of the City. W: R.E. Park, E.W. Burgess, R.D. Mc Kenzie, The City (s. 47-62). Chicago: University of Chicago Press.

Domański R. 1990. Gospodarka przestrzenna. Warszawa: PWN.

Gawryszewski A. 2005. Ludność Polski w XX wieku. Warszawa: Instytut Geografii i Przestrzennego Zagospodarowania PAN.

GUS. 2014. Prognoza dla powiatów i miast na prawie powiatu oraz podregionów na lata 20142050. Warszawa.

Harasimowicz A. 2018. Suburbanizacja a rola obszarów otaczających miasto - ujęcie teoretyczne. Studia Miejskie 29, 115-130. https://doi.org/10.25167/sm2017.029.08

Harris Ch.D., Ullman E.L. 1945. The nature of cities. Annals of the American Academy of Political and Social Science 242(1), 7-17. https://doi.org/10.1177/000271624524200103

Hoyt H. 1939. The Structure and Growth of Residential Neighbourhoods in American Cities. Washington: Federal Housing Administration.

Janas A., Wójcik A., Pietras M. 1999. Tarnobrzeg - gród Leliwitów. Tarnobrzeg: Muzeum Historyczne $\mathrm{m}$. Tarnobrzega.

Jędraszko A. 2005. Zagospodarowanie przestrzenne w Polsce-drogi i bezdroża regulacji ustawowych. Warszawa: Unia Metropolii Polskich.

Kaczmarek T., Kociuba D. 2017. Models of governance in the Urban Functional Areas - policy lessons from implementation of Integrated Territorial Investment (ITI) in Poland. Quaestiones Geographicae 36(4), 51-68. https://doi.org/10.1515/quageo-2017-0035

Kociuba D. 2015a. Miejskie obszary funkcjonalne - wyzwania planistyczne. Studia Miejskie 18, 39-53.

Kociuba D. 2015b. Ograniczenia w rozwoju miast w kontekście planowania przestrzennego. Studia KPZK PAN 161, 112-122.

Kociuba D. 2017. Delimitacja miejskich obszarów funkcjonalnych ośrodków wojewódzkich w realizacji zintegrowanych inwestycji terytorialnych w Polsce - teoria versus praktyka. Studia Regionalne i Lokalne 3(69), 54-78.

Kociuba D. 2018. Implementation of integrated territorial investments in Poland - rationale, results, and recommendations. Quaestiones Geographicae 37(4), 81-98. https://doi.org/10.2478/quageo-2018-0038 
Kociuba. D. 2019. Zmiany granic administracyjnych w Polsce - efekty przestrzenne i społeczno-ekonomiczne. Studia Miejskie 33, 91-113.

Kociuba D. [w druku]. New trends of changes of administrative boundaries in Poland. European Spatial Research and Policy 28(1).

Kosiedowski W. 2008. Zarządzanie rozwojem regionalnym i lokalnym. W: Z. Strzelecki (red.), Gospodarka regionalna i lokalna (s. 221-242). Warszawa: PWN.

Kowalewski A., Mordasewicz J., Osiatyński J., Regulski J., Stępień J., Śleszyński P. 2014. Ekonomiczne straty i społeczne koszty niekontrolowanej urbanizacji w Polsce - wybrane fragmenty raportu. Samorząd Terytorialny 4, 5-21.

Krzysztofik R. 2014. Geneza aglomeracji miast na obszarze Polski. Katowice: Wydawnictwo UŚ.

Kudłacz M. 2016. Dysfunkcje amorficznego rozrostu osadnictwa w Polsce. Studia Ekonomiczne. Zeszyty Naukowe Uniwersytetu Ekonomicznego w Katowicach 279, 245-257.

Kulesza M. 2000. Transformacja ustroju administracyjnego Polski (1990-2000). Studia Iuridica $38,79-86$.

Lisowski A., Grochowski M. 2008. Procesy suburbanizacji. Uwarunkowania, formy i konsekwencje. W: K. Saganowski, M. Zagrzejewska-Fiedorowicz, P. Żuber (red.), Ekspertyzy do Koncepcji Przestrzennego Zagospodarowania Kraju 2008-2033 (T. 1; s. 217-280). Warszawa: Ministerstwo Rozwoju Regionalnego.

Maik W., Parysek J., Wojtasiewicz L. 1978, Podstawowe zagadnienia identyfikacyjne barier wzrostu w gospodarce przestrzennej. Biuletyn KPZK PAN 99, 22-31.

Malisz B., Żurkowski J. 1971. Metoda analizy progowej. Warszawa: PWN.

Małek J. 2011. Historyczne i współczesne uwarunkowania procesów suburbanizacji. Przestrzeń i Forma 16, 431-442.

Michalak T. 1996. Krosno i okolice. Krosno: Roksana.

Mikołajewicz Z. 2003. Ekonomiczne i społeczne skutki procesu transformacji w Polsce. Annales Universitatis Mariae Curie-Skłodowska. Sectio H, Oeconomia 37, 361-373.

Motak M. 2004. Przemyśl. Przemyśl: Urząd Miejski w Przemyślu.

Nowakowska A. 2017. Terytorializacja rozwoju i polityki regionalnej. Biuletyn KPZK PAN 267, 26-38.

Noworól K. 2018. Wpływ instrumentów terytorialnych na rozwój partnerstw wewnątrz- i międzysektorowych w Polsce. Biuletyn KPZK PAN 272, 27-41.

Parysek J.J. 1997. Podstawy gospodarki lokalnej. Poznań: Wydawnictwo Naukowe UAM.

Parysek J.J. 2010. Rola planowania w rozwoju społeczno-gospodarczym i przestrzennym miast polskich po 1989 roku. Studia Miejskie 1, 13-28.

Parysek J.J. 2018. Rozwój społeczno-gospodarczy oraz czynniki i uwarunkowania rozwoju. Studia KPZK PAN 183, 37-56.

Regulski J. 1982. Ekonomika miast. Warszawa: PWE.

Rogowska M. 2010. Endogeniczne determinanty rozwoju lokalnego. Ekonomiczne Problemy Ustug 61, 353-361.

Sekuła A. 2005. Bariery rozwoju lokalnego. Zeszyty Naukowe Uniwersytetu Szczecińskiego 401, $587-600$.

Solon L., Borzyszkowski J., Bidłasik M., Richling A., Badora K., ..., Ziaja W. 2018. Physico-geographical mesoregions of Poland: Verification and adjustment of boundaries on the basis of contemporary spatial data. Geographia Polonica 91(2), 143-170. https://doi.org/10.7163/ GPol.0115

Szafranek E. 2019. Terytorializacja polityki rozwoju. Wdrażanie Zintegrowanych Inwestycji Terytorialnych w obszarach funkcjonalnych miast w Polsce. Studia i Monografie / Uniwersytet Opolski 561,310. 
Szlachta J. 1996. Przestrzenne uwarunkowania polityki rozwoju w Polsce. Prace i Materiaty Instytutu Rozwoju Gospodarczego SGH 52, 7-36.

Szmuc M., Madej K. 2011. Była siarka! I co jest teraz? Górnictwo i Geologia 6(1), 211-221.

Tokarski T., Wilk-Jakubowski G., Misiak T. 2012. Makroekonomiczne zróżnicowanie rozwoju województwa podkarpackiego. Kielce: Stowarzyszenie Współpracy Polska-Wschód.

Tomaszewski P. 2019. Tempo rozwoju społeczno-gospodarczego dawnych miast wojewódzkich, Zeszyty Naukowe Towarzystwa Doktorantów UJ 25, 143-161.

Werwicki A. 1973. Struktura przestrzenna średnich miast ośrodków wojewódzkich w Polsce. Wrocław-Warszawa-Kraków-Gdańsk: Zakład Narodowy im. Osoolińskich, Wydawnictwo PAN.

Wojtkowiak W. 2020. Czwórmiasto nie próżnuje. Samorzady Tarnobrzega, Stalowej Woli, Niska i Sandomierza planuja wspólna strategię rozwoju i nie tylko. Pobrane z: https://echodnia. eu/podkarpackie/czwormiasto-nie-proznuje-samorzady-tarnobrzega-stalowej-woli-niska-isandomierza-planuja-wspolna-strategie-rozwoju-i-nie-tylko/ar/c1-15219406

\section{Dokumenty strategiczno-planistyczne}

KPZK 2030: Koncepcja Przestrzennego Zagospodarowania Kraju 2030. 2011. Warszawa: Ministerstwo Rozwoju Regionalnego (M.P. 2012, poz. 252).

PZPWP 2030: Plan Zagospodarowania Przestrzennego Województwa Podkarpackiego z Perspektywą do 2030 r. (L1X/930/18).

SUiKZP Krosna 2016: Studium Uwarunkowań i Kierunków Zagospodarowania Przestrzennego Miasta Krosna. 2016. (XXXV/708/16).

SUiKZP Przemyśla 2017: Studium Uwarunkowań i Kierunków Zagospodarowania Przestrzennego Miasta Przemyśla. 2017. (68/2017).

SUiKZP Tarnobrzega 2017: Studium Uwarunkowań i Kierunków Zagospodarowania Przestrzennego Miasta Tarnobrzega. 2017. (XLVI/457/2017).

\section{Akty prawne}

Rozporządzenie Rady Ministrów z dnia 31 lipca 2020 r. w sprawie ustalenia granic niektórych gmin i miast, nadania niektórym miejscowościom statusu miasta, zmiany nazwy gminy oraz siedziby władz gminy (Dz.U. 2020, poz. 1332).

Uchwała nr 239 Rady Ministrów z dnia 13 grudnia 2011 r. w sprawie przyjęcia Koncepcji Przestrzennego Zagospodarowania Kraju 2030 (M.P. 2012, poz. 252).

Ustawa z dnia 8 marca 1990 r. o samorządzie gminnym (Dz.U. 1990, nr 16, poz. 95 ze zm.).

Ustawa z dnia 7 lipca 1994 r. o zagospodarowaniu przestrzennym (Dz.U. 1994, nr 89, poz. 415 ze zm.).

Ustawa z dnia 24 lipca 1998 r. o wprowadzeniu zasadniczego trójstopniowego podziału terytorialnego państwa (Dz.U. 1998, nr 96, poz. 603).

Ustawa z dnia 27 marca 2003 r. o planowaniu i zagospodarowaniu przestrzennym (Dz.U. 2003, nr 80 , poz. 717 ze zm.).

\section{Strony internetowe}

www.bdl.stat.gov.pl

www.gis.umkrosno.pl

www.mapy.geoportal.gov.pl

www.przemysl.geoportal2.pl

www.stat.gov.pl

www.tarnobrzeg.geoportal2.pl 